\title{
Idaho National Laboratory Research Center Renewal Application for the Industrial Wastewater Acceptance Permit Number IF-8733-54171-1
}

January 2018

The INL is a U.S. Department of Energy National Laboratory operated by Battelle Energy Alliance 



\title{
Idaho National Laboratory Research Center Renewal Application for the Industrial Wastewater Acceptance Permit Number IF-8733-54171-1
}

\author{
January 2018
}

Idaho National Laboratory Idaho Falls, Idaho 83415

http://www.inl.gov

Prepared for the U.S. Department of Energy Under DOE Idaho Operations Office Contract DE-AC07-05ID14517 

INL/EXT-18-44401

IDAHO NATIONAL LABORATORY RESEARCH CENTER RENEWAL APPLICATION FOR THE INDUSTRIAL WASTEWATER ACCEPTANCE PERMIT NUMBER IF-8733-54171-1 



\section{CITY OF IDAHO FALLS \\ INDUSTRIAL USER FACT SHEET}

Facility Name:_Idaho National Laboratory Research Center (IRC, Buildings IF-601, IF-602. IF603, IF-611, IF-627, IF-638, IF-655, IF-657, and IF-732)

Facility Address: __2351 North Boulevard

City:_Idaho Falls State:_[D Zip Code: _

Mailing Address:_P.O. Box 1625

City:_Idaho Falls State:_ID Zip Code: $\_83415$

Phone:_208-526-7740 Fax: _208-526-5848

Contact \# 1: James Graham Title: BEA Staff

Email Address: James.Graham@inl.gov Cell Number: 208-680-5844

Contact \# 2: Mike Lewis Title: _BEA Staff

Email Address: Michael.Lewis@inl.gov Cell Number: 208-569-4924

Contact \# 3: _Joy Kibbee Title: BEA Staff

Email Address: Joy.Kibbee@inl.gov Cell Number: 208-589-4707

Type of Business:_Government Research and Development

Products Manufactured: None

Operating Schedule: 7:00 AM-4:30 PM Monday through Thursday and 7:00 AM to 3:30 PM every other Friday

Number of Employees: Approximately 240

SIC Code: $\_\underline{8733}$ NAICS Code:

Maximum Daily Flow: 30,000 gallons (estimated) Average Daily Flow: $\underline{30,000 \text { gallons }}$ (estimated)

Building Modifications Planned: No building modifications are currently planned 



\section{CITY OF IDAHO FALLS \\ INDUSTRIAL PRETREATMENT DISCLOSURE FORM}

COMPLETE ALL APPLICABLE SECTIONS. INFORMATION MUST BE TYPED OR CLEARLY PRINTED. ATTACH INFORMATION AS NEEDED. SIGNING OFFICIAL MUST HAVE AUTHORIZATION TO PROVIDE SUCH INFORMATION ON BEHALF OF THE COMPANY.

1. Company Name:_Battelle Energy Alliance, LLC; Idaho National Laboratory (INL)

(Please print or type)

2. Division Name (if applicable): Idaho National Laboratory Research Center (IRC, Buildings IF-601, IF-602, IF603, IF-611, IF-627, IF-638, IF-655, IF-657, and IF-732)

3. Mailing Address: a. Street or PO Box:_P.O. Box 1625

b. City, State \& Zip Code: Idaho Falls, ID 83402

4. Facility Address: a. Street or PO Box: 2351 North Boulevard

b. City, State \& Zip Code:_Idaho Falls, ID 83402

5. Type of Business: Government Research and Development

6. Final Product Manufactured:_ No products are manufactured

7. SIC: NAICS: 541715

((Standard Industrial Classification)

(North American Industry Classification System)

8. Wastewater Constituents:

Parameter

Concentration (MG/L)

- Arsenic

$<0.04$

_Cadmium

$<0.26$

Chromium

$<2.77$

_Copper

$<1.93$

_Cyanide

$<1.04$

_Lead

$<0.29$

_Mercury

$<0.002$

_Nickel

$<2.38$

_Oil and Grease (petroleum or mineral oil)

$<100$

_ Oil and Grease (animal and vegetable)

$<250$

_Silver

$\leq 0.43$

_Zinc

$<0.90$

$\mathrm{pH}$

.0 and not $>9.0$ 


\section{Wastewater Average Daily Discharge Flow:}

Process: 23,000 gallons (estimated) Sanitary: _4,600 gallons (estimated)

Cooling: 2,400 gallons (estimated)_Total: 30,000 gallons (estimated)

a. Daily, Monthly, Seasonal Variation: Steady

b. Time and Duration of Discharge: Continuous

10. Discharge to wastewater system: Attach as Exhibit “A” a plan to the property showing accurately the site plan, floor plan, sewers, sewer connections, inspections manholes, and sampling chambers by size, location. See Exhibit A.

11. Description of facility: Attach as Exhibit "B" a description of the activities, facilities and plant processes, including all materials discharged to the sewers or treatment facilities. See Exhibit B.

12. Prohibited pollutants being discharged as regulated by City Sewer Use Ordinance.

*POLLUTANT

None
CONCENTRATION (MG/L)

DAILY MAXIMUM DAILY AVERAGE

* Chemical Classification:

Flammable Explosive Corrosive Reactive

Noxious/Fuming Toxic Radioactive Inhibitory to POTW

13. Is Industry in compliance with City Industrial Pretreatment Ordinance? ___

14. Is additional pretreatment required? (Yes) $\underline{X} \underline{X}($ No).

If yes, describe pretreatment necessary

15. Compliance Schedule: (Must conform to requirements of City Pretreatment Ordinance). Attach Additional sheets as necessary.

Not Applicable

16. Products produced: (Attach additional sheets as necessary). 
$\underline{\text { IRC facilities are used for research. No products }}$ are produced.

17. Raw materials used, to include chemicals used in process that could be discharged to sanitary System: (Attach additional sheets as necessary). See Exhibit $\mathbf{C}$.

\section{AMOUNT UTILIZED}

TYPE

AVERAGE/DAY

MAXIMUM/DAY

18. Environmental control permits: List any environmental control permits held by or for your facility.

Injection well permit \#25-W-062-001 for the IRC closed loop cooling system.

Industrial Wastewater Acceptance Permit No. IF-8733-54171-1

Telephone:

Date: $1 / 2 / / 6$

Owner/Manager: David B. Lively

(Please print or type)

Organization /Title: Research and Education Campus, Facility and Site Services/Facilities Operations and Maintenance Manager

Address: P.O. Box 1625, MS 2206

City: Idaho Falls

State: ID

Zip Code: $\underline{83415}$

Email: David.Lively@inl.gov

I certify under penalty of law that this document and all attachments were prepared under my direction or supervision in accordance with a system designed to assure that qualified personnel properly gather and evaluate the information submitted. Based on my inquiry of the person or persons who manage the system, or those persons directly responsible for gathering the information, the information submitted is, to the best of my knowledge and belief, true, accurate, and complete. I am aware that there are significant penalties for submitting false information, including the possibility of fine and imprisonment for knowing violations.

Signature:

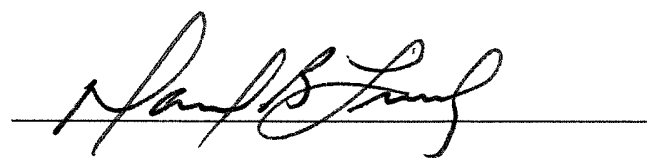





\section{ACCIDENTAL SPILL PREVENTION PLAN}

Facility Name:INL Research Center (Buildings IF-601, IF-602, IF-603, IF-611, IF-627, IF-638, IF-655, IF-657, IF-732)

Facility Address: 2351 North Boulevard

City: Idaho Falls State: $\underline{\text { ID }}$ Zip Code:

Mailing Address:_P.O. Box 1625, Mail Stop 3406

City: Idaho Falls State: ID Zip Code: $\_\underline{83415}$

Phone:_208-526-7740 Fax: $\_208-526-5848$

Contact \# 1: James Graham Title: BEA Staff

Email:_James.Graham@inl.gov

Contact \# 2: _Mike Lewis Title:_BEA Staff

Email:_Michael.Lewis@inl.gov_PPhone:_208-526-0623_Fax: 208-526-3149

Type of Business: _ Government Research and Development

Products Manufactured: _None

Operating Schedule: 7:00 AM-4:30 PM Monday -Thursday and 7:00 AM -3:30 PM every other Friday

Number of Employees:_240

SIC Code: $\_8733$ NAICS Code:

1. Facility Layout and Flow Diagram: Attach copy addressing facility layout, entrance and exits, chemical storage areas, manufacturing area and floor drains, floor sumps and oil and sand interceptors. See Exhibits A and B.

2. Chemical Data: List chemical names, maximum volume, chemical storage location, disposal method and documentation of disposal, copies of the Material Safety Data Sheets. See Exhibit C. Material Safety Data Sheets are available on request.

\section{Spill and leak prevention equipment: See Exhibit D}

4. Emergency Response and procedures: Attach copy of procedures. See Exhibit D 
5. Spill Reporting: Attach list and documentation that employees have been trained on what to do in the event of an accidental spill. Who and when to contact, list of each agency and phone numbers that employees would use in case of an emergency. See Exhibit D 


\section{Exhibit A}

Idaho National Laboratory Research Center (IRC) Site Plan, Underground Utilities Drawing, and Facility Floor Plans 
A-2 


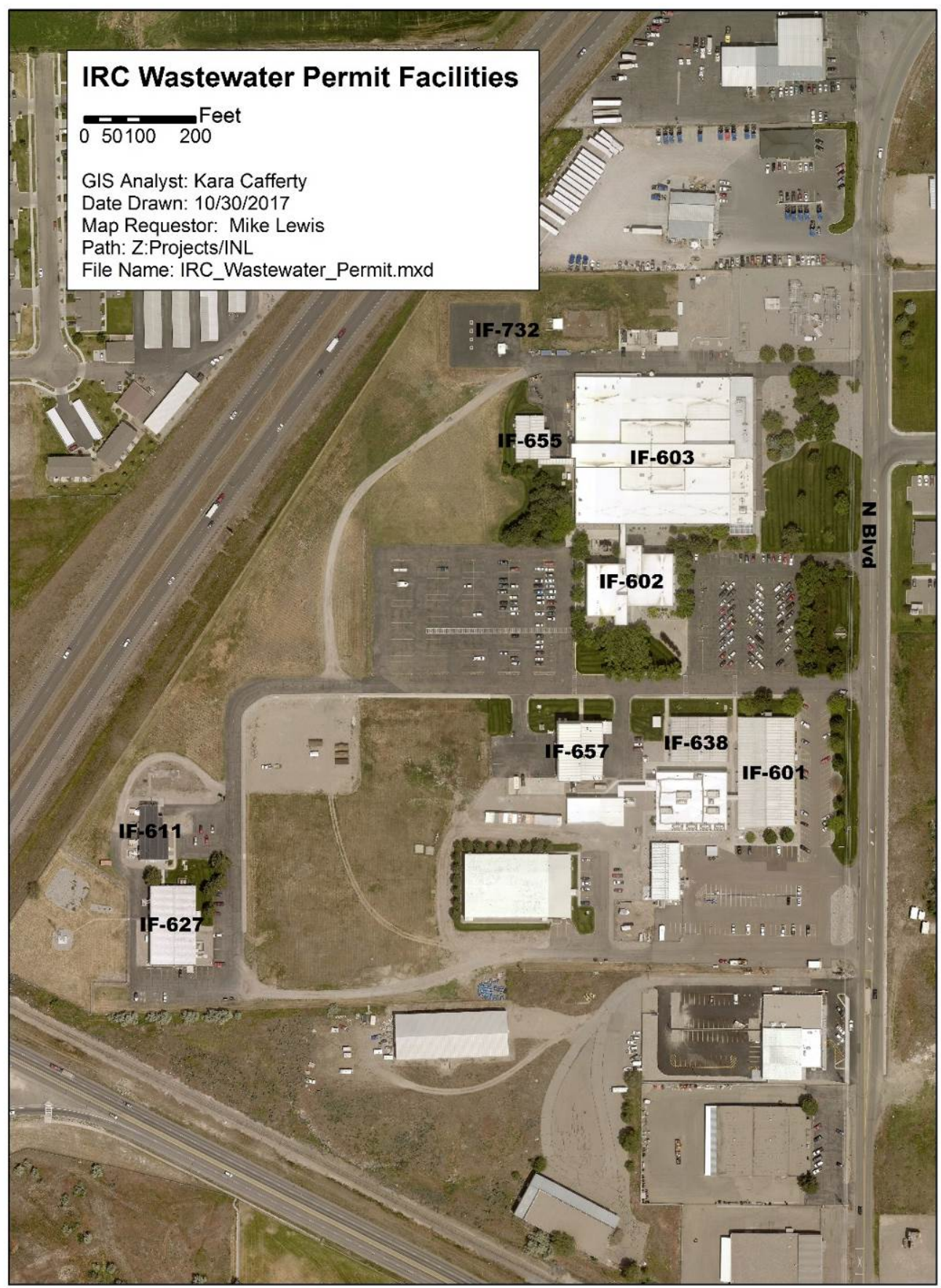

Figure A-1. Site plan showing location of IRC permitted buildings. 


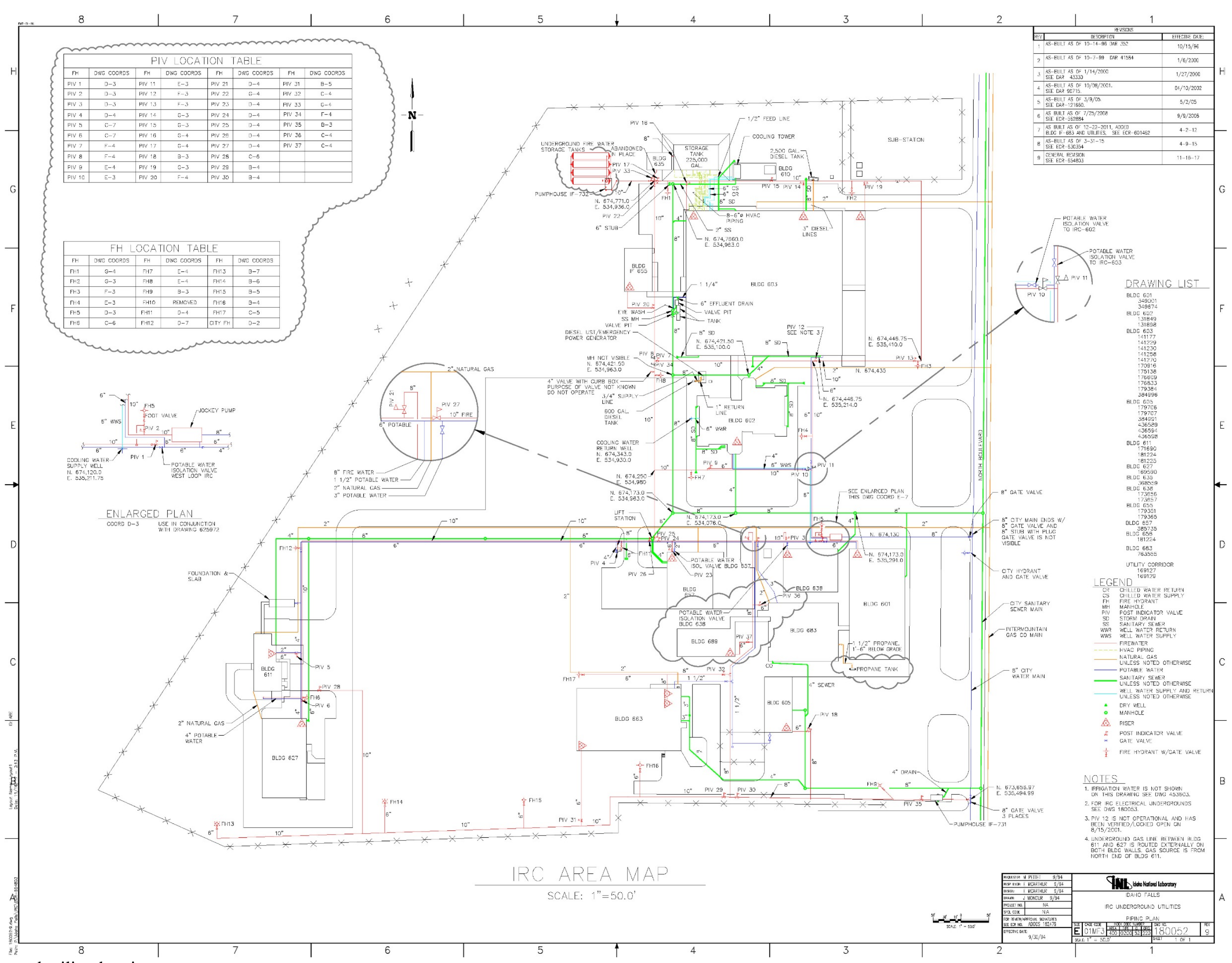

Figure A-2. IRC underground utility drawing. 



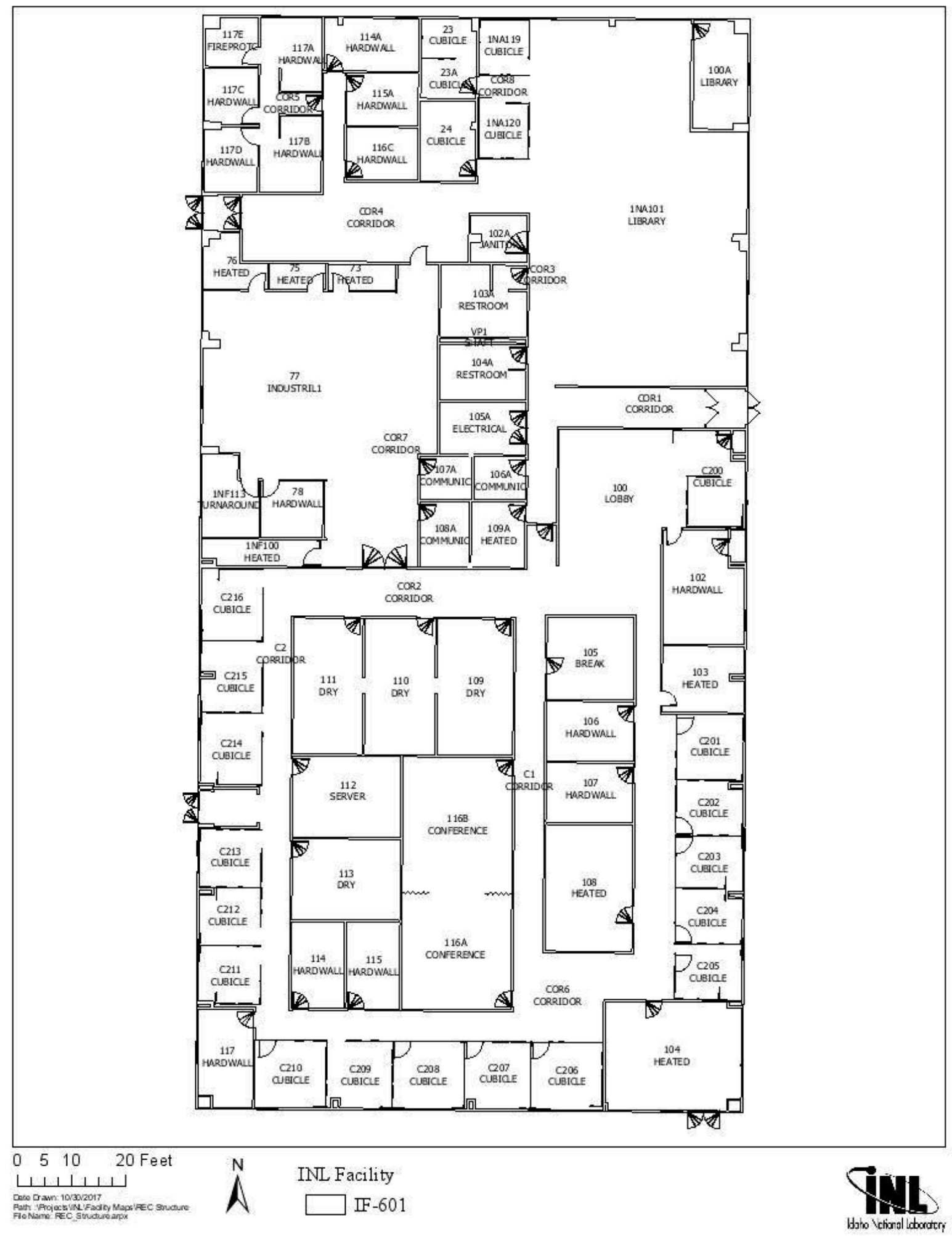

Figure A-3. IRC Radiological and Environmental Sciences Office (IF-601) floor plan. 


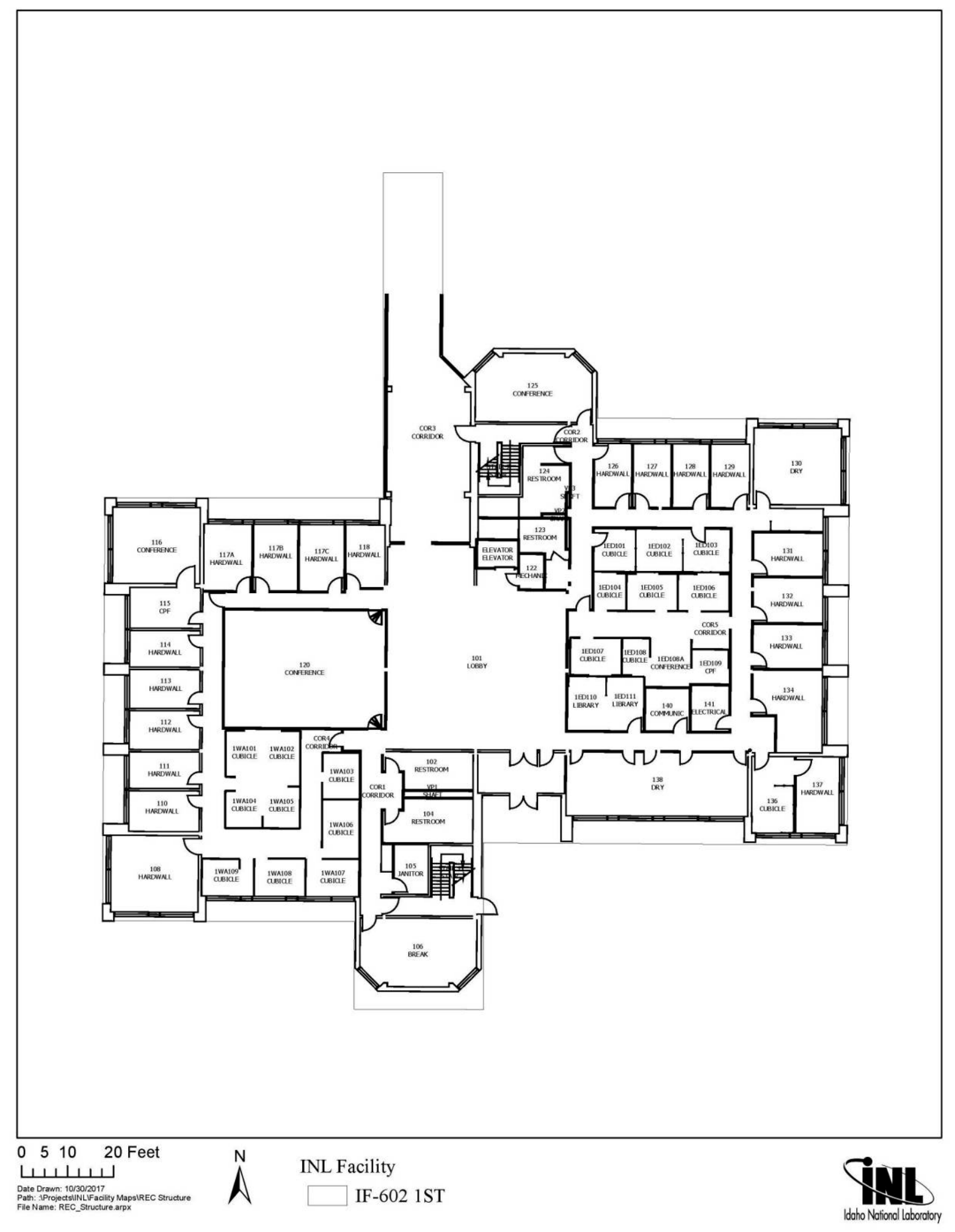

Figure A-4. IRC Office Building (IF-602) floor plan (1st floor). 


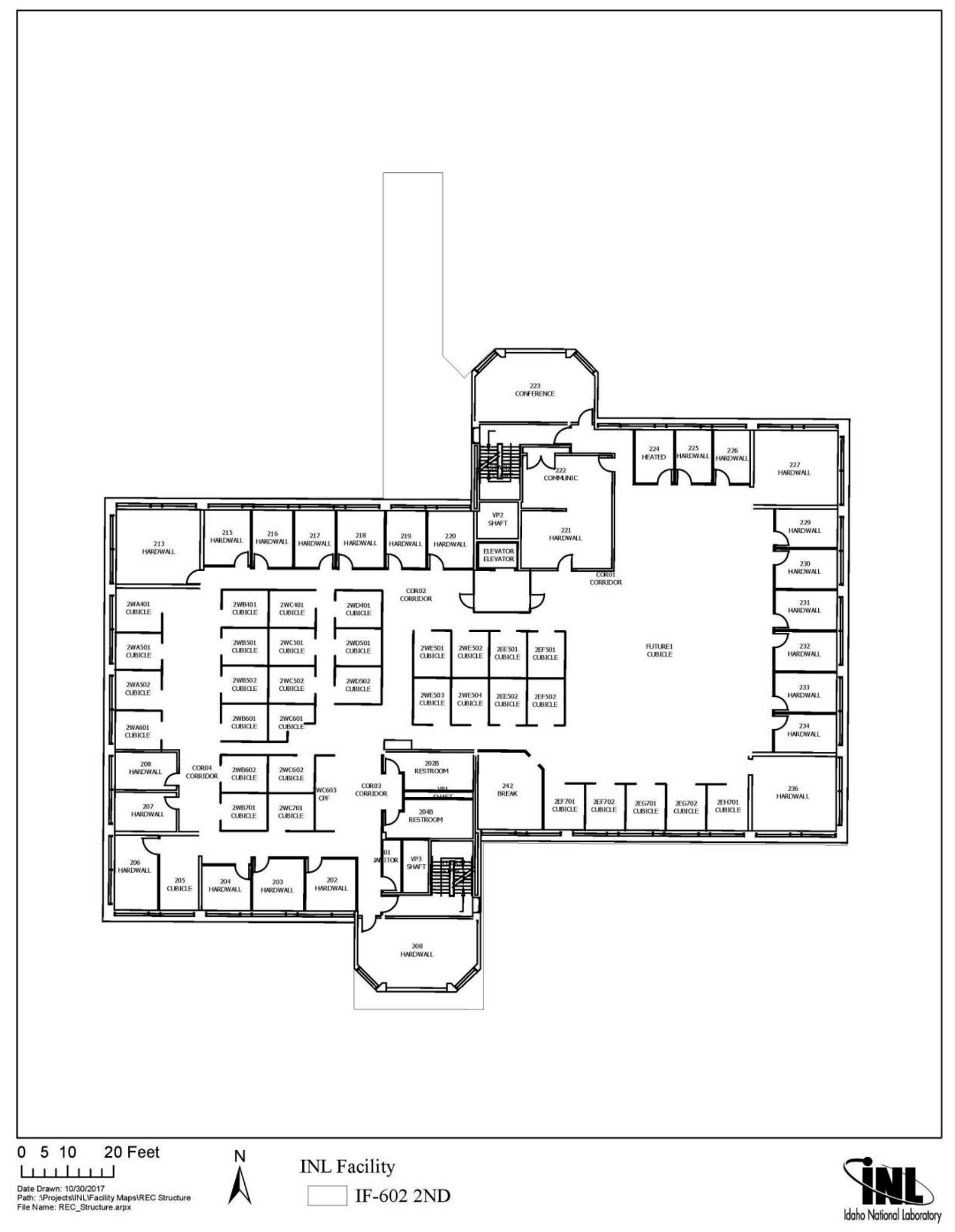

Figure A-5 IRC Office Building (IF-602) floor plan (2nd floor). 


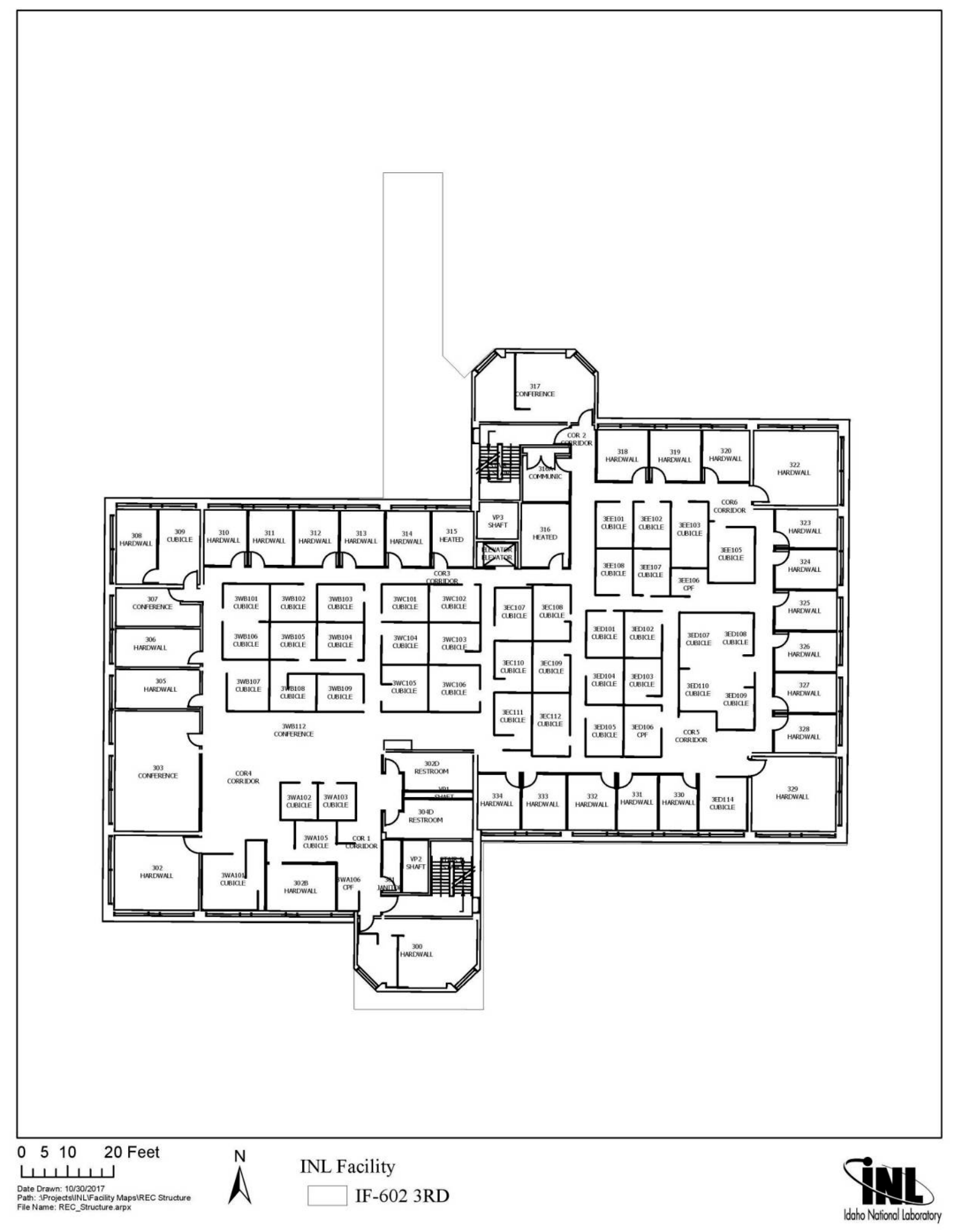

Figure A-6. IRC Office Building (IF-602) floor plan (third floor). 


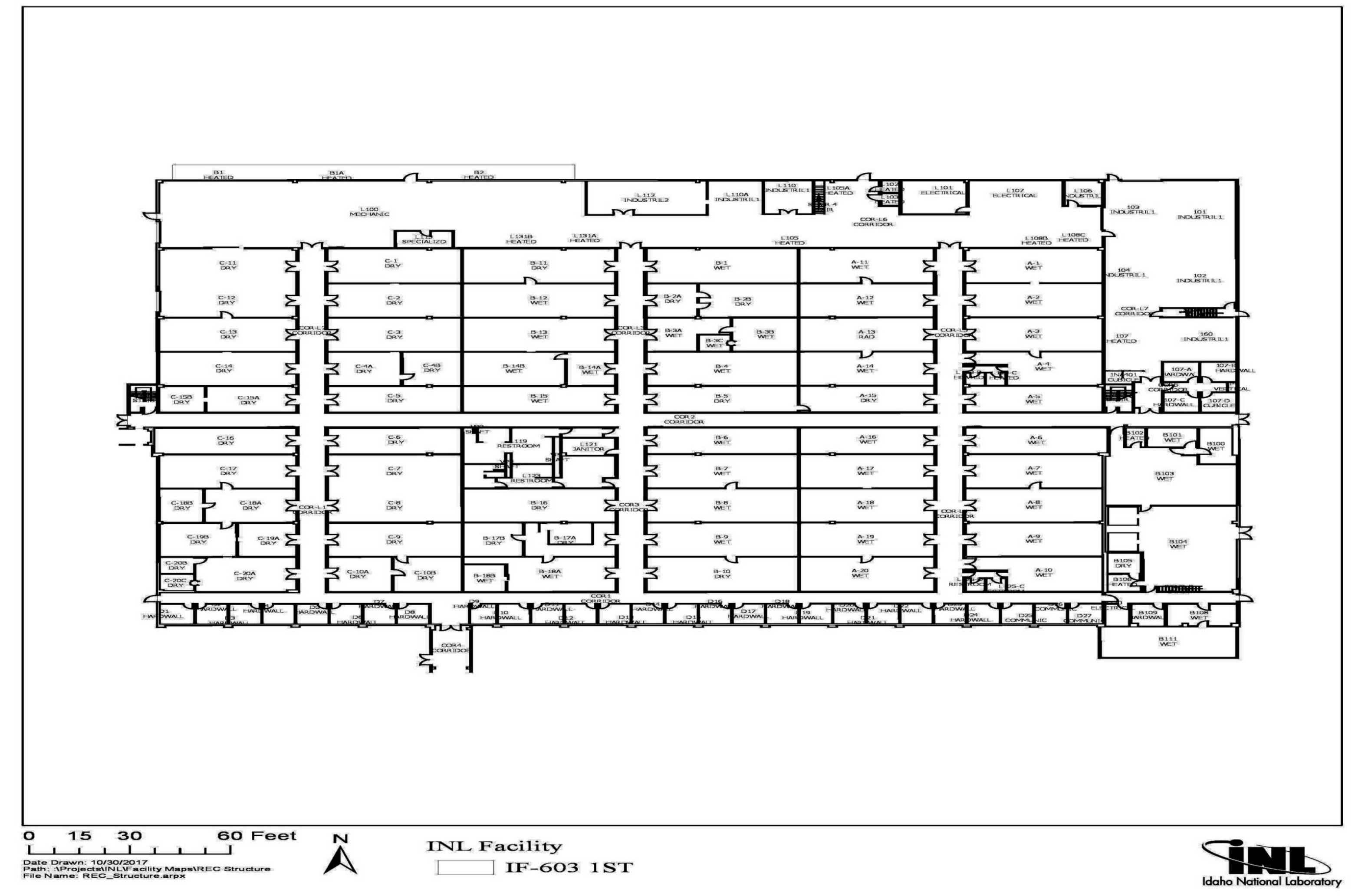

Figure A-7 IRC Laboratory Building (IF-603) floor plan (1 $1^{\text {st }}$ floor). 



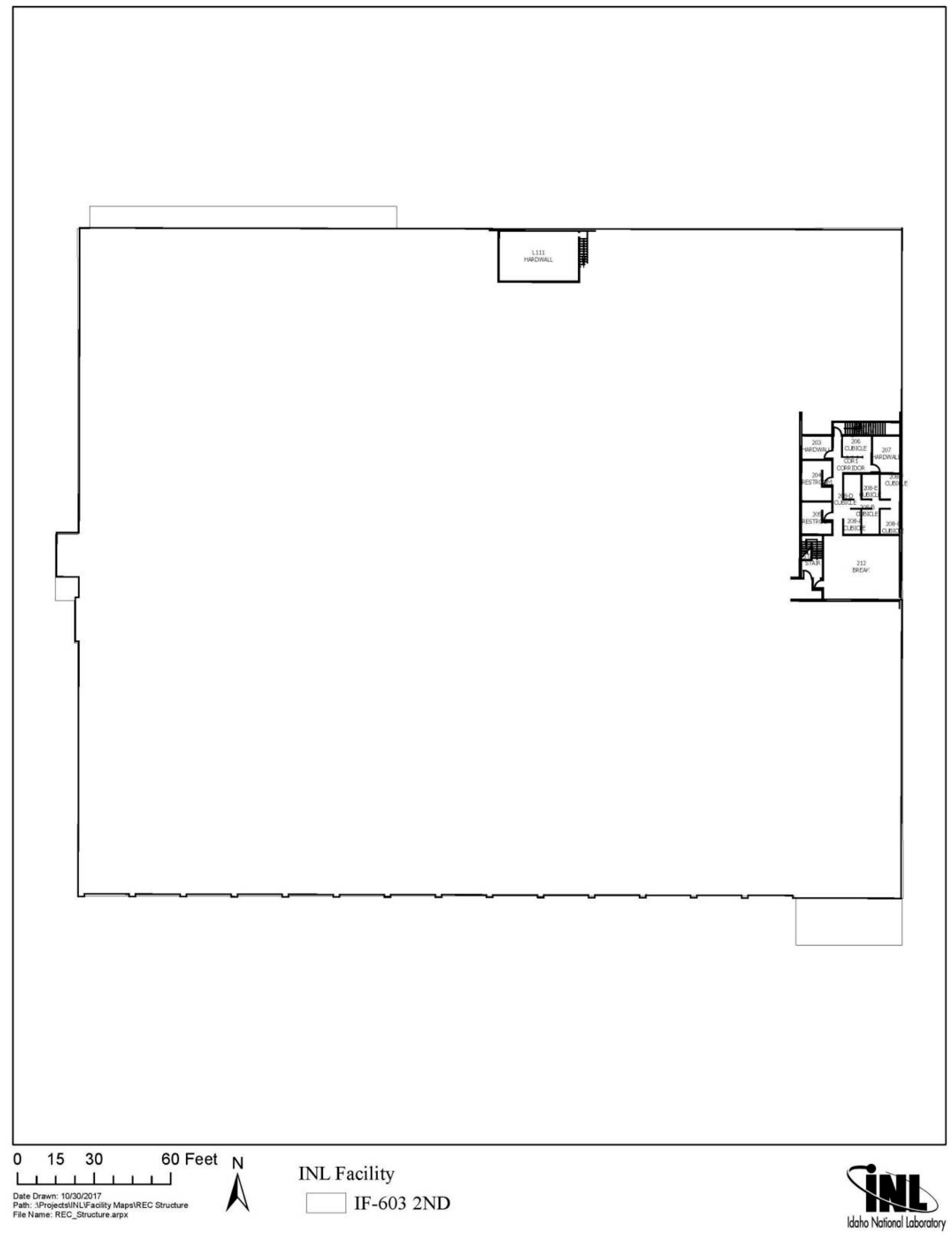

Figure A-8. IRC Laboratory Building (IF-603) floor plan ( $2^{\text {nd }}$ floor). 


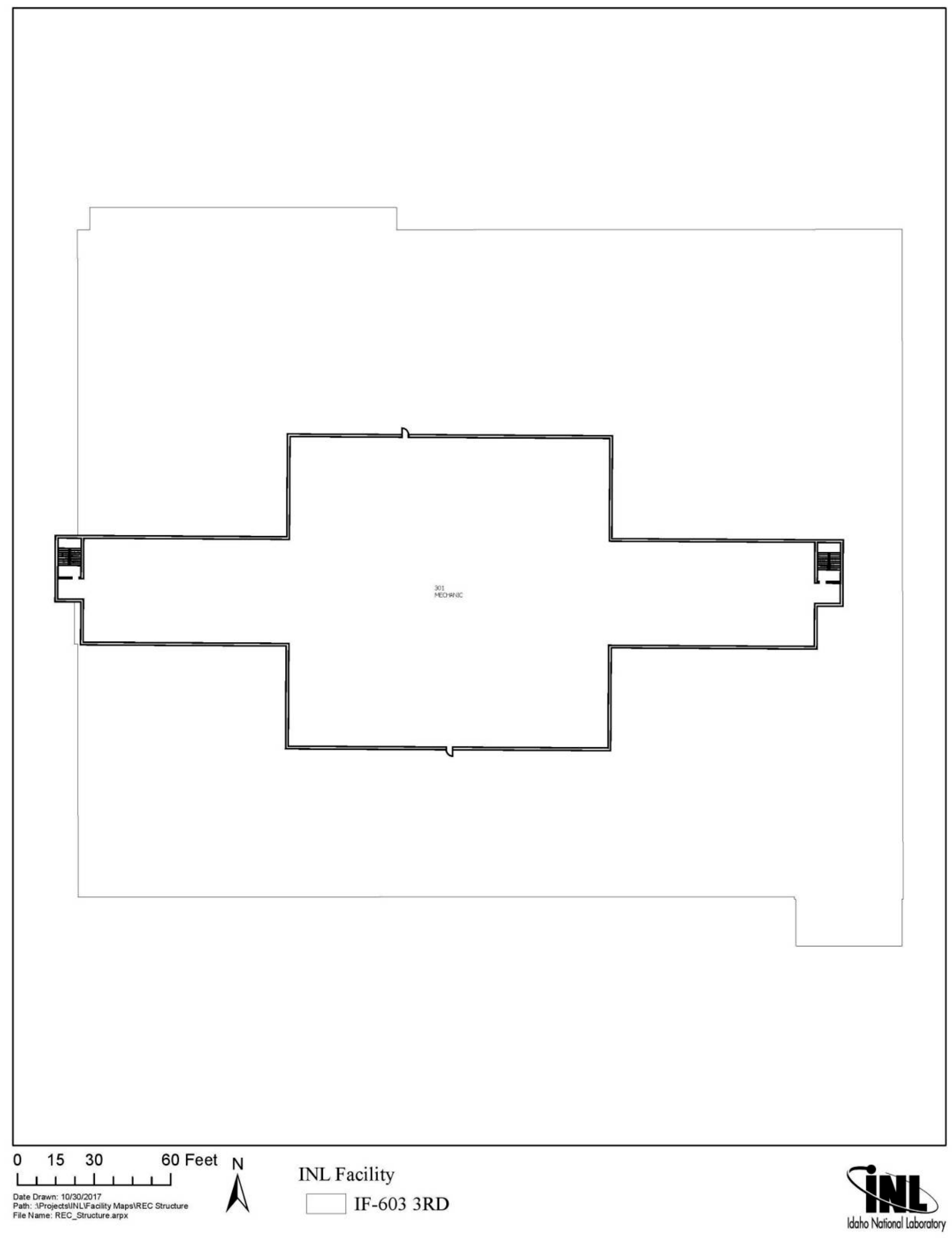

Figure A-9. IRC Laboratory Building (IF-603) floor plan ( $3^{\text {rd }}$ floor). 


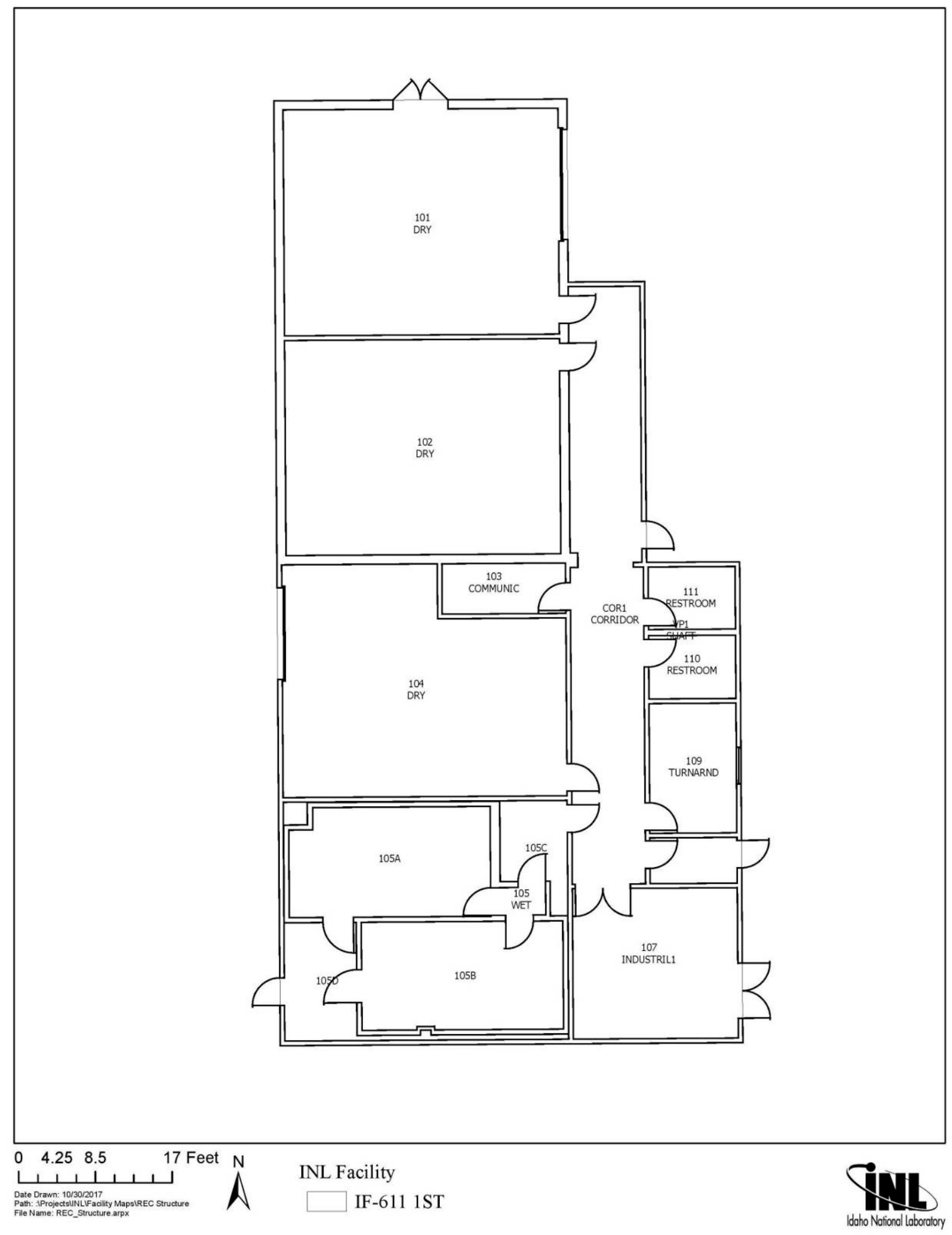

Figure A-10. IRC National Security Laboratory (IF-611) floor plan. 


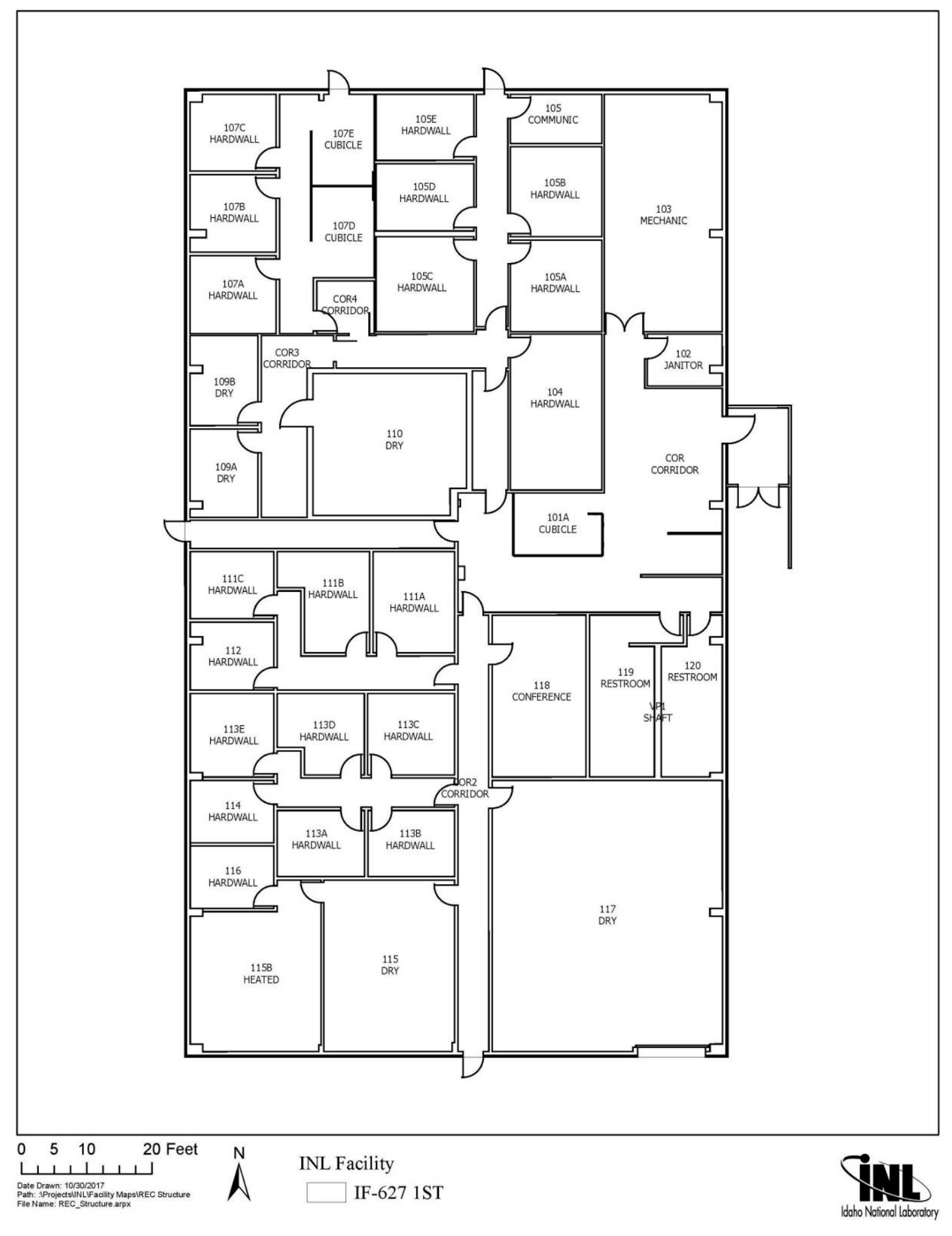

Figure A-11. IRC Systems Analysis Facility (IF-627) floor plan. 


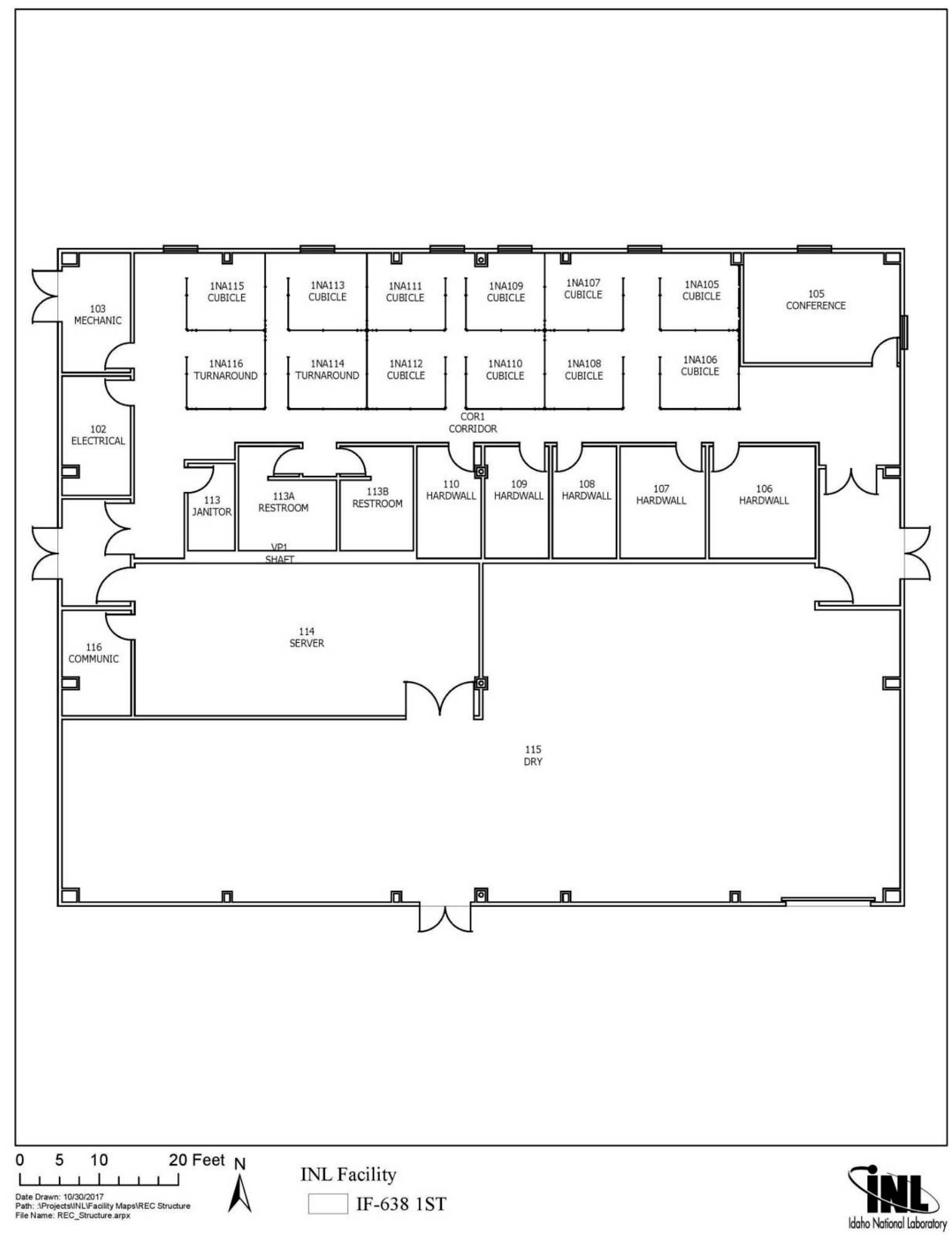

Figure A-12. IRC Physics Lab (IF-638) floor plan. 


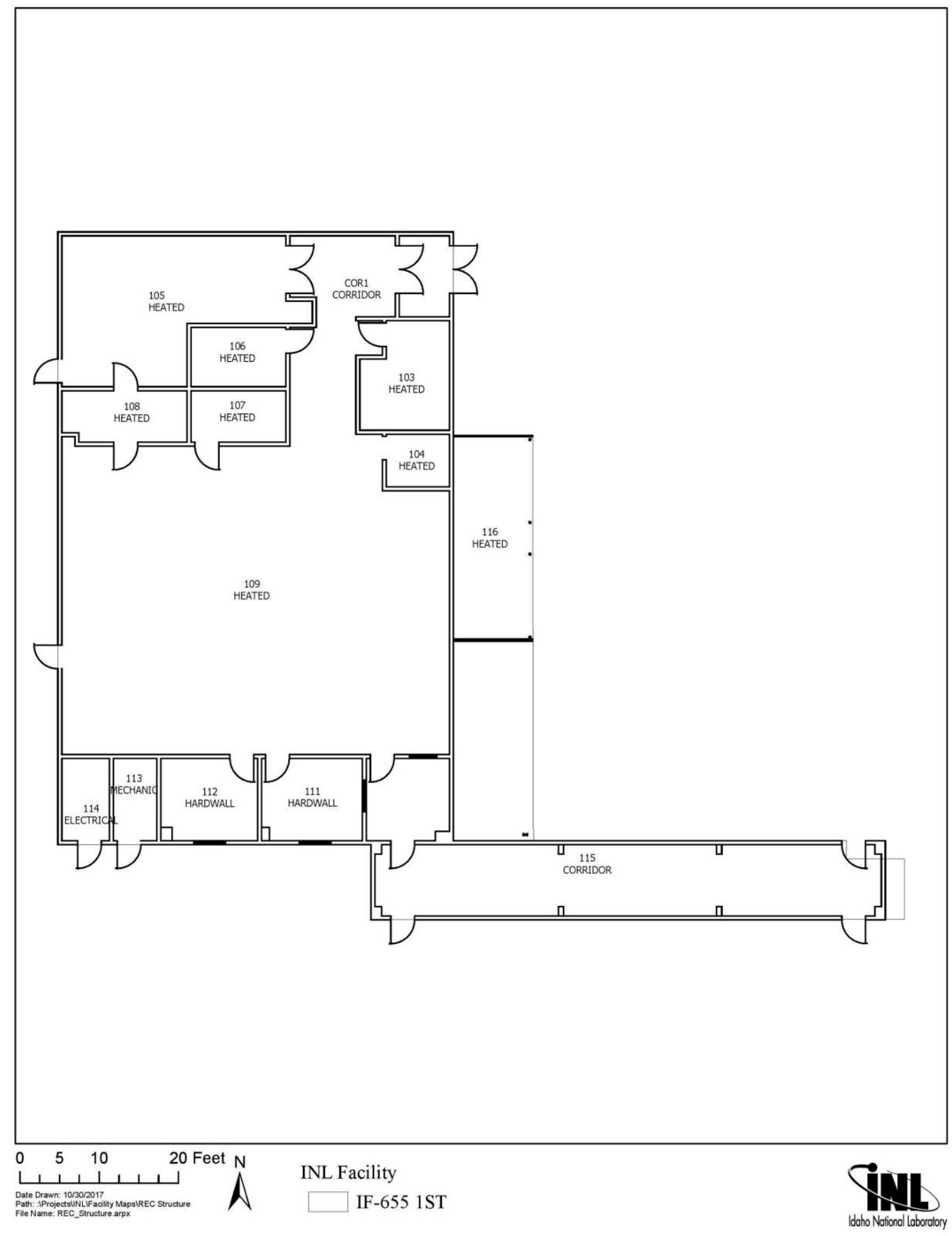

Figure A-13. IRC Chemical Storage Facility (IF-655) floor plan. 


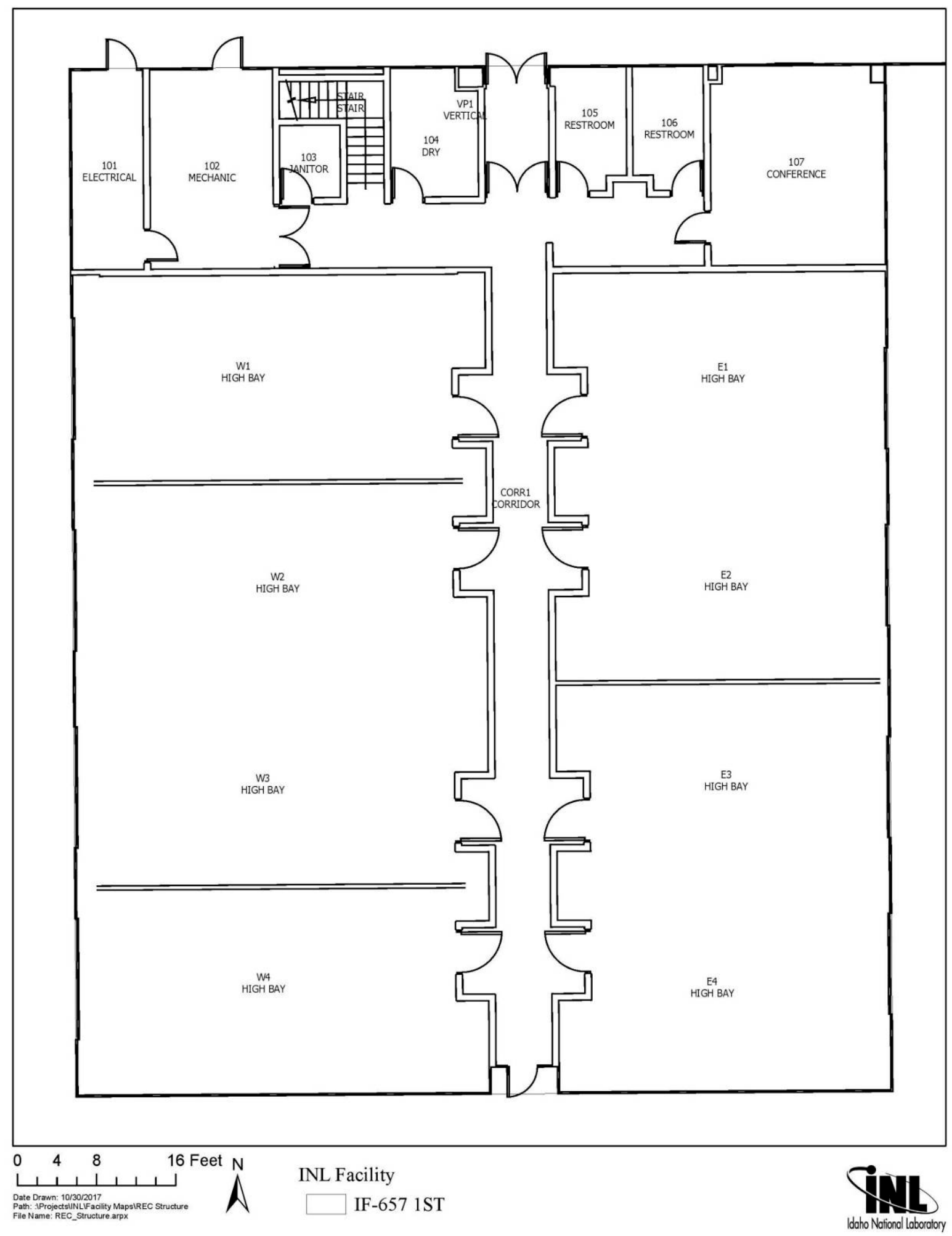

Figure A-14. IRC Idaho National Laboratory Engineering Demonstration Facility (IF-657) floor plan ( $1^{\text {st }}$ floor $)$. 


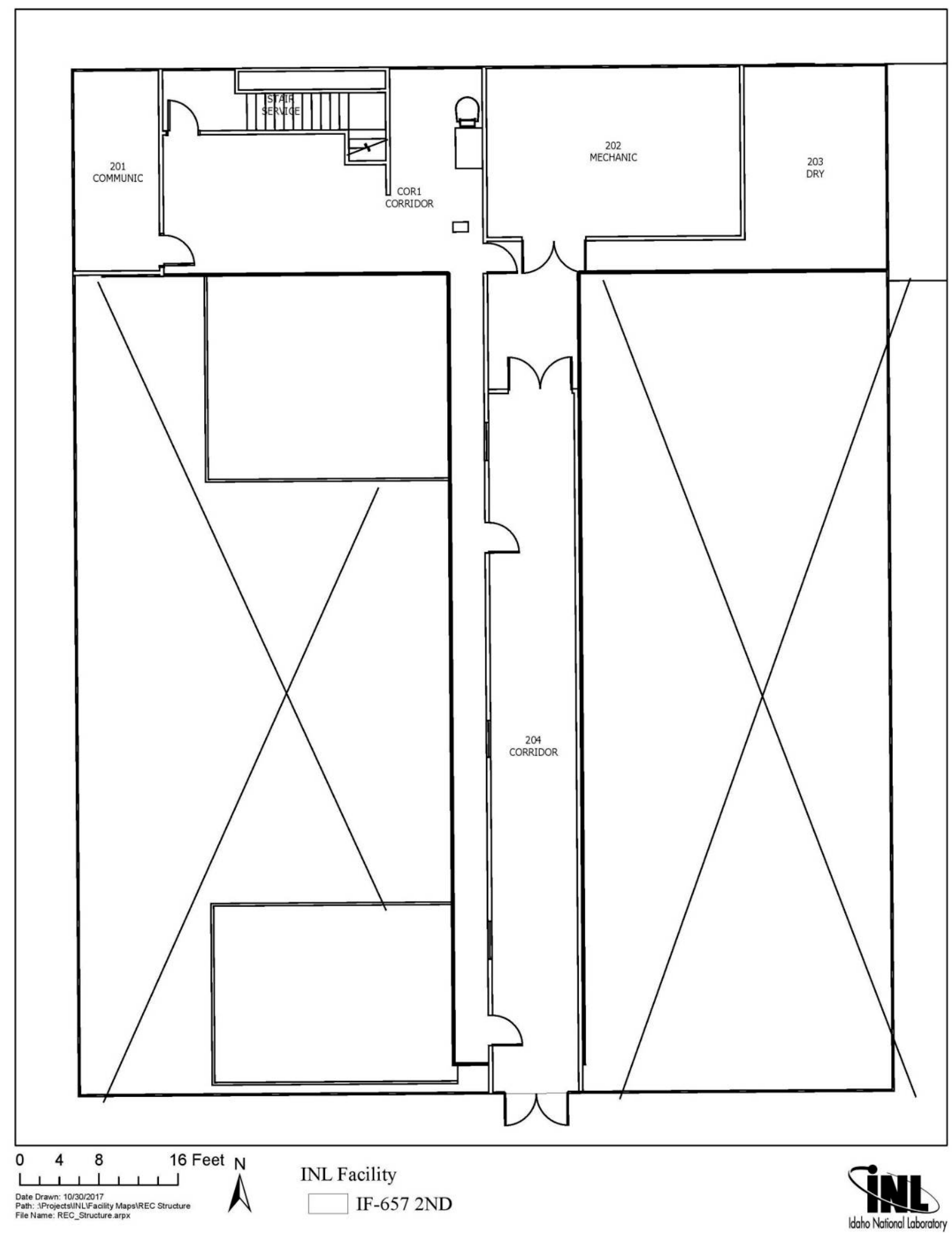

Figure A-15. IRC Idaho National Laboratory Engineering Demonstration Facility (IF-657) floor plan $\left(2^{\text {nd }}\right.$ floor $)$. 


\section{Exhibit B}

\section{Facility Descriptions}


B-2 


\section{Idaho National Laboratory Research Center Radiological and Environmental Sciences Office (IF-601)}

\section{Facility Activity Description:}

The Idaho National Laboratory Research Center Radiological and Environmental Sciences Office (IF-601) is owned by the Department of Energy and is operated by Battelle Energy Alliance, LLC.

This facility is used for offices and includes a men's and women's restroom and janitorial room with a sink.

Discharges to the City of Idaho Falls sewer system include drinking fountains, typical sanitary wastewater from the restrooms (sinks and toilets) and liquid from janitorial cleaning activities.

Administrative controls, identified in PLN-3530 (Accidental Spill Prevention Plan), are in place to ensure all discharges are in compliance with the sewer permit conditions. 


\section{Idaho National Laboratory Research Center Office Building (IF-602)}

\section{Facility Activity Description:}

The Idaho National Laboratory Research Center Office Building (IF-602) is owned by the Department of Energy and is operated by Battelle Energy Alliance, LLC.

Building IF-602 has three floors and serves as an office building. Each floor has one or more men's and women's restrooms. Each floor also has a janitorial room and sink.

Discharges to the City of Idaho Falls sewer system include drinking fountains, typical sanitary wastewater from the restrooms (showers, sinks, and toilets), liquid from janitorial cleaning activities, and non-contact cooling water.

Administrative controls, identified in PLN-3530 (Accidental Spill Prevention Plan), are in place to ensure all discharges are in compliance with the sewer permit conditions. 


\section{Idaho National Laboratory Research Center Laboratory Building \\ (IF-603)}

\section{Facility Activity Description:}

The Idaho National Laboratory Research Center Laboratory Building (IF-603) is owned by the Department of Energy and is operated by Battelle Energy Alliance, LLC. The facility is used for office space, research and development activities. There are 66 laboratories located in this facility. Each laboratory contains utility sinks and floor drains (sealed where practical) that drain to the city sewer.

The facility is used principally for experimental research dedicated to a wide range of research activities, analytical techniques, and other facility support functions, such as facility maintenance. Unlike a production facility, the research activities in this building typically use a wide array of chemicals in very small quantities.

The normal route of release from the facility to the city sewer system is through the restrooms, laboratory sinks, and non-contact cooling water. The liquid waste from the restrooms is normal sanitary wastewater. Small amounts of chemicals, excluding radionuclides, attached to instruments and/or glassware are sometimes washed into the city sewer system.

Radionuclides are used in some of the laboratory activities. These include sealed and unsealed radioactive materials. Quantities of unsealed radionuclides presently allowed in IF-603 are limited to amounts less than a hazard category 3 nuclear facility threshold as defined in "DOE1027-92, Hazard Categorization and Accident Analysis Techniques for Compliance with DOE Order 5480.23, Nuclear Safety Analysis Reports."

The $\mathrm{pH}$ of the liquid effluent from IF-603 laboratories is continuously monitored. The monitoring station is downstream from the point where laboratory effluent enters the stream and upstream of the point where sewage enters the sewer system. An alert is received if the $\mathrm{pH}$ approaches the city sewer limit. If the alarm is triggered, the effluent is temporarily detained and neutralized.

Administrative controls, identified in PLN-3530 (Accidental Spill Prevention Plan), are in place to ensure all discharges are in compliance with the sewer permit conditions. 


\section{Idaho National Laboratory Research Center National Security Laboratory (IF-611)}

\section{Facility Activity Description:}

The Idaho National Laboratory Research Center National Security Lab (IF-611) is owned by the Department of Energy (DOE) and operated by Battelle Energy Alliance, LLC.

Activities occurring in IF-611 include typical office activities and research programs. Discharges to the City of Idaho Falls sewer system include typical sanitary wastewater from the restrooms (sinks and toilets), air compressor blowdown, water softener regeneration, and a water heater.

Radionuclides are used in some of the laboratory activities. These include sealed and unsealed radioactive materials. Quantities of unsealed radionuclides presently allowed in IF-611 are limited to amounts less than a hazard category 3 nuclear facility threshold, as defined in "DOE1027-92, Hazard Categorization and Accident Analysis Techniques for Compliance with DOE Order 5480.23, Nuclear Safety Analysis Reports.

Laboratory environments include standard chemistry and biotechnology, physics, electronics, and materials (welding, machining, etc.). Small quantities of laboratory chemicals, excluding radionuclides, are discharged, however, administrative controls, identified in PLN-3530 (Accidental Spill Prevention Plan), are in place to ensure all discharges are in compliance with the sewer permit conditions. 


\section{Idaho National Laboratory Research Center Systems Analysis Facility \\ (IF-627)}

\section{Facility Activity Description:}

The Idaho National Laboratory Research Center Systems Analysis Facility (IF-627) is owned by the Department of Energy and is operated by Battelle Energy Alliance, LLC. Facility is utilized primarily as office space with a separate lab area. This lab is used for glass blowing activities.

There is a sink in the glass shop. Non-contact cooling water from the glass saws, mill, and sander are discharged into the drain.

There is a men's and women's restroom, a janitorial room with a sink, and a kitchen area with a sink. There are also discharges from air handling units, a water heater, and an air compressor.

Administrative controls, identified in PLN-3530 (Accidental Spill Prevention Plan), are in place to ensure all discharges are in compliance with the sewer permit conditions. 


\section{Idaho National Laboratory Research Center Physics Laboratory (IF-638)}

\section{Facility Activity Description:}

The Idaho National Laboratory Research Center Physics Laboratory (IF-638) is owned by the Department of Energy and is operated by Battelle Energy Alliance, LLC.

Approximately half of the building is used as office space.

The rest of the facility is used as a physics research laboratory. The laboratory houses nuclear physics experiments supporting arms control, technical transfer, spent fuel characterization, radiation detection system development, and development of nondestructive examination and assay systems. The research involves the development of nuclear and non-nuclear instrumentation to be used in collaboration in basic research and direct programmatic efforts.

Radionuclides are used in some of the laboratory activities. These include sealed and unsealed radioactive materials. Quantities of unsealed radionuclides presently allowed in IF-638 are limited to amounts less than a hazard category 3 nuclear facility threshold, as defined in "DOE1027-92, Hazard Categorization and Accident Analysis Techniques for Compliance with DOE Order 5480.23, Nuclear Safety Analysis Reports.

The facility includes a men's and women's restroom and a janitorial room with a sink. Other liquid effluents include potable water used for nondestructive tests, and discharges from air handling units and a water heater.

Administrative controls, identified in PLN-3530 (Accidental Spill Prevention Plan), are in place to ensure all discharges are in compliance with the sewer permit conditions. 


\section{Idaho National Laboratory Research Center \\ Chemical Storage Facility \\ (IF-655)}

\section{Facility Activity Description:}

The Idaho National Laboratory Research Center (IRC) Chemical Storage Facility (IF-655) is owned by the Department of Energy and is operated by Battelle Energy Alliance, LLC.

Facility IF-655 is utilized primarily as a safe and environmentally sound storage area for management of chemicals associated with IRC activities. The building was designed for chemical management following applicable guidelines in the Uniform Building Codes, National Fire Protection Association, and conforms to other safety and environmental requirements for buildings used for chemical storage and management. There are offices occupied by personnel responsible for the daily operation of IF-655.

The Chemical Storage Facility has no restrooms or janitorial rooms/sinks and no floor drains. There are several safety eyewash/shower stations located throughout the building. Water from these stations would drain to the floor and/or into one of several concrete sumps (without drains). Water and any associated chemicals would be cleaned up and disposed in accordance with all applicable requirements and regulations.

There are two sinks with faucets that drain to the City sewer system. The sinks are only used for hand washing. Actual chemical use in the facility is limited to standard office and janitorial cleaning products. No hazardous chemicals are discharged to the sinks.

Administrative controls, identified in PLN-3530 (Accidental Spill Prevention Plan), are in place to ensure all discharges are in compliance with the sewer permit conditions. 


\section{Idaho National Laboratory Research Center Engineering Demonstration Facility \\ (IF-657)}

\section{Facility Activity Description:}

The Idaho National Laboratory Research Center (IRC) Engineering Demonstration Facility (IF657) is owned by the Department of Energy and is operated by Battelle Energy Alliance, LLC.

\section{Major activities that are performed in the IRC Engineering Demonstration Facility include:}

Bay E1 and E2. Matched Index of Refraction (MIR) test system. This system is designed to be able to test flow patterns of liquid or wind around an object or within a piping system. The system utilizes a laminar flow of high purity mineral oil pumped through a closed loop into which is inserted the test object/system. The disturbance to the laminar flow of oil is recorded for analysis of ways to improve flow through a system, or areas of potential impacts. This project is currently on hold until further funding is available.

Bay E3 and E4: Structural Dynamics Testing. The test setup consists of a reaction frame, two electrical actuators, soil box, structure models, and soil specimens to determine the interaction between structures and soils under the simulated seismic conditions representing real-life demands for the safety-critical structures and nuclear power plants.

Bay W1: Cold Crucible Induction Melter (CCIM). This pilot plant system demonstrates the reduction and immobilization of simulated slurry and sludge wastes (i.e., mostly surrogate radioactive High-Level -Wastes (HLWs) from Hanford legacy defense operations and future proposed raffinates from commercial nuclear fuel recycling) to a solid glass, glass/ceramic or multiple phase pure ceramic waste form prior to final disposal. In contrast to the current methods of deploying corrosive prone in-bed electrodes and refractory, this cost effective, higher waste throughput melter and associated off-gas system uses a 60KW RF induction coil to heat the simulated HLW and additives in a nonconductive/ transparent 10.4 inch diameter crucible constructed of water cooled tubes-to temperatures above 1500 degrees C. Upon crucible tapping, draining and cooling, the CCIM produces a high waste mass loaded, low volume glass/ceramic like waste form. As a result, this waste form is highly durable (i.e., very resistant to both radionuclide and hazardous material leaching) for 100s of thousands of years. This project is currently on hold until further funding is available.

Bay W2: This bay houses cabinets and other experimental equipment such as casks that are used to test prior to use in the field. No waste is currently generated that would enter the drains.

Bay W3: SPECTR. A large vacuum/pressure furnace designed to test the efficiency and effects of heat and pressure on heat exchangers. The furnace uses a closed loop cooling system to maintain seal integrity and keep surface temperatures below $50^{\circ} \mathrm{C}$. 
Bay W4. Tristructural Isotropic Fuel Oxidation Tests, Channel Gap Probe System. First is a mock up system designed to measure the spacing between fuel plates before and after exposure in a reactor to determine deformation of the plates after irradiation. This system is used to test the tools and equipment using surrogate radiological and non-radiological test specimens prior to installing the tools on an identical system at the Advanced Test Reactor. This system is immersed in a large water tank full of deionized water when tests are performed. Second is a non-radioactive benchtop testing of a horizontal tube furnace, test gas preparation equipment/methodology, gas analysis instrumentation, and other supporting systems/instrumentation to test thermomechanical integrity of ceramic furnace tube materials (e.g., $\mathrm{ZrO} 2, \mathrm{Al} 2 \mathrm{O} 3$, and $\mathrm{SiC}$ ). Particular attention will be paid to thermal stress resistance at temperatures up to $1600^{\circ} \mathrm{C}$. The furnace is contained within a polycarbonate enclosure. Connections between the ceramic tube and metal piping will be tested at temperatures of about $150^{\circ} \mathrm{C}$. Trace heating of the portions of the furnace tube (and other tubing) extending outside of the furnace will be tested. The temperature profiles within the furnace and the furnace tube will be measured at various furnace temperature set points, and thermocouple placements throughout the furnace.

The facility has a men's and women's restroom, a break room with a sink, and a compressor room. Discharges include sanitary wastewater and water from air handling units, a water softener, a water heater, and an air compressor.

There is a sink in all of the bays, with the exception of Bay E2. Special design criteria for the facility include impervious concrete floors and walls. Floor drains are routed to sublevel holding areas and then to a sump. The sump accumulates liquids that are then discharged to the city sewer system. Discharges consist of various liquid discharges from the bench scale equipment.

Administrative controls, identified in PLN-3530 (Accidental Spill Prevention Plan), are in place to ensure all discharges are in compliance with the sewer permit conditions. 


\section{Idaho National Laboratory Research Center \\ North Firewater Pump House \#1 \\ (IF-732)}

\section{Facility Activity Description:}

The Idaho National Laboratory Research Center North Firewater Pump House \#1 (IF-732) is owned by the Department of Energy and operated by Battelle Energy Alliance, LLC.

There is a 300 gallon diesel fuel tank for the firewater pump.

The only discharge from this building to the city sewer system is from noncontact cooling water.

Administrative controls, identified in PLN-3530 (Accidental Spill Prevention Plan), are in place to ensure all discharges are in compliance with the sewer permit conditions. 


\section{Exhibit C}

\section{Chemical List by Building}


C-2 
Table C-1. IF-601 maximum chemical inventory, in pounds, for the period of December 1, 2016 through November 30, 2017.

\begin{tabular}{|l|c|c|}
\hline Chemical CAS & Chemical Name & Maximum (lbs) $^{\mathbf{a}}$ \\
\hline $1310-73-2$ & Sodium hydroxide & 2.5402335 \\
\hline $8042-47-5$ & mineral oil & 3.051279 \\
\hline $7681-52-9$ & Sodium hypochlorite & 3.328668 \\
\hline $193-39-5$ & Indeno(1,2,3-cd)pyrene & 10.9956 \\
\hline $205-99-2$ & Benzo[b]fluoranthene & 10.9956 \\
\hline $207-08-9$ & Benzo(k)fluoranthene & 10.9956 \\
\hline $218-01-9$ & Benzo(a)phenanthrene & 10.9956 \\
\hline $50-32-8$ & Benzo[a]pyrene & 10.9956 \\
\hline $53-70-3$ & Dibenz[a,h]anthracene & 10.9956 \\
\hline $56-55-3$ & Benz[a]anthracene & 10.9956 \\
\hline $71-43-2$ & Benzene & 10.9956 \\
\hline $7439-92-1$ & Lead & 10.9956 \\
\hline $7440-38-2$ & Arsenic & 10.9956 \\
\hline $7440-43-9$ & Cadmium & 10.9956 \\
\hline $1310-73-2$ & Sodium hydroxide & 2.5402335 \\
\hline a. Only chemicals of one pound or greater are shown in this table. & \\
\hline
\end{tabular}


Table C-2. IF-602 maximum chemical inventory, in pounds, for the period of December 1, 2016 through November 30, 2017.

\begin{tabular}{|l|l|l|}
\hline Chemical CAS & \multicolumn{1}{|c|}{ Chemical Name } & \multicolumn{1}{c|}{ Maximum (lbs) $^{\mathbf{a}}$} \\
\hline $8042-47-5$ & mineral oil & 2.061675 \\
\hline $1310-73-2$ & Sodium hydroxide & 2.12415 \\
\hline \multicolumn{2}{|l}{ a. Only chemicals of one pound or greater are shown in this table. } \\
\hline
\end{tabular}


Table C-3. IF-603 maximum chemical inventory, in pounds, for the period of December 1, 2016 through November 30, 2017.

\begin{tabular}{|c|c|c|}
\hline Chemical CAS & Chemical Name & Maximum (lbs) $^{\mathrm{a}}$ \\
\hline $10294-34-5$ & Borane, trichloro- & 1 \\
\hline $134-32-7$ & alpha-Naphthylamine & 1.041961922 \\
\hline $84-74-2$ & Dibutyl phthalate & 1.060386063 \\
\hline $75-36-5$ & Acetyl chloride & 1.080265204 \\
\hline 7726-95-6 & Bromine & 1.093286294 \\
\hline 10101-89-0 & Sodium phosphate, tribasic & 1.102311432 \\
\hline $3164-29-2$ & Ammonium tartrate & 1.102311432 \\
\hline $62-56-6$ & Thiourea & 1.102311432 \\
\hline $7773-06-0$ & Ammonium sulfamate & 1.102311432 \\
\hline $65-85-0$ & Benzoic acid & 1.104516054 \\
\hline $628-63-7$ & Amyl acetate & 1.112516125 \\
\hline $75-07-0$ & Acetaldehyde & 1.313879927 \\
\hline $141-78-6$ & Ethyl acetate & 1.323128107 \\
\hline 7783-06-4 & Hydrogen sulfide & 1.46188477 \\
\hline $71-55-6$ & 1,1,1-Trichloroethane & 1.530472649 \\
\hline $1341-49-7$ & Ammonium bifluoride & 1.653467148 \\
\hline $107-15-3$ & 1,2-Ethanediamine & 2.024320156 \\
\hline $7722-64-7$ & Potassium permanganate & 2.160530408 \\
\hline $79-00-5$ & 1,1,2-Trichloroethane & 2.200553164 \\
\hline $1111-78-0$ & Ammonium carbamate & 2.204622865 \\
\hline $7778-54-3$ & Calcium hypochlorite & 2.204622865 \\
\hline $71-36-3$ & n-Butyl alcohol & 2.206853009 \\
\hline $27323-41-7$ & $\begin{array}{l}\text { Triethanolamine dodecylbenzene } \\
\text { sulfonate }\end{array}$ & 2.443897134 \\
\hline $85-68-7$ & Butyl benzyl phthalate & 2.456093934 \\
\hline $62-75-9$ & $\begin{array}{l}\text { Methanamine, N-methyl-N- } \\
\text { nitroso- }\end{array}$ & 2.853025 \\
\hline $96-09-3$ & Styrene oxide & 2.853025 \\
\hline $7446-09-5$ & Sulfur dioxide & 3.091966358 \\
\hline $7664-39-3$ & Hydrofluoric acid & 3.234565256 \\
\hline $506-87-6$ & Ammonium carbonate & 3.284888068 \\
\hline 7601-54-9 & Sodium phosphate, tribasic & 3.46528 \\
\hline $3012-65-5$ & Ammonium citrate dibasic & 3.527396582 \\
\hline 10192-30-0 & Ammonium bisulfite & 3.900943958 \\
\hline $127-18-4$ & Perchloroethylene & 4.239115924 \\
\hline $108-95-2$ & Phenol & 4.322376423 \\
\hline $7758-29-4$ & Sodium phosphate, tribasic & 4.374767072 \\
\hline $110-16-7$ & Maleic acid & 4.376176387 \\
\hline $75-56-9$ & Oxirane, methyl- & 4.450086071 \\
\hline $58-36-6$ & Phenoxarsine, 10,10'-oxydi- & 4.558013279 \\
\hline 631-61-8 & Ammonium acetate & 4.608084045 \\
\hline 7439-97-6 & Mercury & 5.00007716 \\
\hline $108-10-1$ & Methyl isobutyl ketone & 5.071473591 \\
\hline $123-31-9$ & Hydroquinone & 5.16119597 \\
\hline $156-60-5$ & 1,2-Dichloroethylene & 5.165192692 \\
\hline $111-42-2$ & Diethanolamine & 5.538566068 \\
\hline
\end{tabular}




\begin{tabular}{|c|c|c|}
\hline 109-99-9 & Furan, tetrahydro- & 5.646777125 \\
\hline & & \\
\hline 123-91-1 & 1,4-Dioxane & 5.878479335 \\
\hline $68-12-2$ & Dimethylformamide & 6.257056366 \\
\hline 1066-33-7 & Ammonium bicarbonate & 6.613868593 \\
\hline 1314-62-1 & Vanadium pentoxide & 6.756 \\
\hline $79-34-5$ & 1,1,2,2-Tetrachloroethane & 6.987816724 \\
\hline 108-94-1 & Cyclohexanone & 7.010046106 \\
\hline $123-86-4$ & Butyl acetate & 7.070368791 \\
\hline 7722-84-1 & $\begin{array}{c}\text { Hydrogen peroxide (Conc.> } \\
52 \%)\end{array}$ & 7.23888909 \\
\hline $60-00-4$ & $\begin{array}{l}\text { Ethylenediamine-tetraacetic acid } \\
\text { (EDTA) }\end{array}$ & 7.292366193 \\
\hline $67-72-1$ & Hexachloroethane & 7.759585935 \\
\hline $100-42-5$ & Styrene & 7.982649353 \\
\hline $106-42-3$ & Benzene, p-dimethyl- & 8.257911333 \\
\hline $106-42-3$ & Benzene, p-dimethyl- & 8.257911333 \\
\hline $7664-41-7$ & Ammonia & 8.699095873 \\
\hline 10043-01-3 & Aluminum sulfate & 8.708796126 \\
\hline $75-21-8$ & Ethylene oxide & 8.754465764 \\
\hline $64-18-6$ & Formic acid & 9.458099229 \\
\hline $7681-52-9$ & Sodium hypochlorite & 10.27975095 \\
\hline $75-05-8$ & Acetonitrile & 10.37590881 \\
\hline 7782-63-0 & Ferrous sulfate & 10.93492941 \\
\hline $79-06-1$ & Acrylamide & 10.98474012 \\
\hline $110-54-3$ & Hexane & 11.18865841 \\
\hline $25155-30-0$ & Sodium dodecylbenzenesulfonate & 12.14219303 \\
\hline $540-84-1$ & 2,2,4-Trimethylpentane & 12.38421251 \\
\hline $27176-87-0$ & Dodecylbenzenesulfonic acid & 12.495 \\
\hline 1336-21-6 & Ammonium hydroxide & 12.69462051 \\
\hline $79-01-6$ & Trichloroethylene & 12.75073208 \\
\hline $98-82-8$ & Cumene & 13.62703762 \\
\hline $110-82-7$ & Cyclohexane & 13.90789325 \\
\hline $7440-36-0$ & Antimony & 14.7138151 \\
\hline $12125-02-9$ & Ammonium chloride & 14.91049467 \\
\hline 7786-81-4 & $\begin{array}{l}\text { Nickel sulfate } \\
\end{array}$ & 15.06897 \\
\hline 7558-79-4 & Sodium phosphate, dibasic & 16.34816647 \\
\hline 7720-78-7 & Ferrous sulfate & 18.73929435 \\
\hline $67-66-3$ & Chloroform & 19.38140241 \\
\hline $75-09-2$ & Dichloromethane & 22.10657064 \\
\hline $7440-22-4$ & Silver & 23.00604651 \\
\hline $78-93-3$ & Methyl ethyl ketone & 23.13064897 \\
\hline 7646-85-7 & Zinc chloride & 23.9802613 \\
\hline $64-19-7$ & Acetic acid & 27.10967391 \\
\hline $7723-14-0$ & Phosphorus & 36.92660295 \\
\hline $71-43-2$ & Benzene & 41.1685538 \\
\hline $100-41-4$ & Ethylbenzene & 41.54447251 \\
\hline 7647-01-0 & Hydrochloric acid & 50.28478936 \\
\hline
\end{tabular}




\begin{tabular}{|l|c|c|}
\hline $75-71-8$ & CFC-12 & 52.54418666 \\
\hline $91-20-3$ & Naphthalene & 54.20870089 \\
\hline $7681-49-4$ & Sodium fluoride & 56.95803684 \\
\hline $7664-38-2$ & Phosphoric acid & 57.13945989 \\
\hline $75-69-4$ & & 59.94006592 \\
\hline $1330-20-7$ & CFC-11 & 82.58676515 \\
\hline $7664-93-9$ & Xylene (mixed isomers) & 89.85901941 \\
\hline $7697-37-2$ & Sulfuric acid & 89.98223244 \\
\hline $7440-38-2$ & Nitric acid & 91.88616825 \\
\hline $7440-43-9$ & Arsenic & 92.08967838 \\
\hline $7632-00-0$ & Cadmium & 92.90768218 \\
\hline $50-00-0$ & Sodium nitrite & 96.45817125 \\
\hline $1310-73-2$ & Formaldehyde & 100.6610995 \\
\hline $7439-92-1$ & Sodium hydroxide & 116.7901723 \\
\hline $67-64-1$ & Lead & 121.6802462 \\
\hline $8042-47-5$ & Acetone & 125.3574148 \\
\hline $108-88-3$ & mineral oil & 132.7478377 \\
\hline $7440-66-6$ & Toluene & 166.1177683 \\
\hline $67-56-1$ & Zinc & 167.2415449 \\
\hline $1310-58-3$ & Methanol & 190.3787864 \\
\hline $7440-50-8$ & Potassium hydroxide & 414.618966 \\
\hline $107-21-1$ & Copper & 509.996097 \\
\hline $57-55-6$ & Ethylene glycol & 521.2922946 \\
\hline $7440-47-3$ & propylene glycol & 528.1067845 \\
\hline $7440-02-0$ & Chromium & 939.3841434 \\
\hline a. Only chemicals of one pound or greater are shown in this table. & \\
\hline & & \\
\hline & Nickel & \\
\hline
\end{tabular}


Table C-4. IF-611 maximum chemical inventory, in pounds, for the period of December 1, 2016 through November 30, 2017.

\begin{tabular}{|l|c|c|}
\hline Chemical CAS & Chemical Name & Maximum (lbs) $^{\mathbf{a}}$ \\
\hline $7722-64-7$ & Potassium permanganate & 1.080265204 \\
\hline $7631-90-5$ & Sodium bisulfite & 1.091288318 \\
\hline $7722-84-1$ & Hydrogen peroxide (Conc. $>$ & 1.095875475 \\
\hline $7782-63-0$ & $52 \%)$ & 1.102311432 \\
\hline $67-64-1$ & Ferrous sulfate & 1.856968253 \\
\hline $7664-39-3$ & Acetone & 1.965864168 \\
\hline $1762-95-4$ & Hydrofluoric acid & 2.204622864 \\
\hline $7758-29-4$ & Sodium phosphate, tribasic & 2.24 \\
\hline $7439-92-1$ & Lead & 3.003755067 \\
\hline $7647-01-0$ & Hydrochloric acid & 3.023560047 \\
\hline $7632-00-0$ & Sodium nitrite & 3.527396584 \\
\hline $8042-47-5$ & mineral oil & 3.881775781 \\
\hline $75-21-8$ & Ethylene oxide & 4.20665 \\
\hline $7664-93-9$ & Sulfuric acid & 4.828013641 \\
\hline $1336-21-6$ & Ammonium hydroxide & 7.578705096 \\
\hline $7697-37-2$ & Nitric acid & 8.101589536 \\
\hline $1310-73-2$ & Sodium hydroxide & 12.09521845 \\
\hline a. Only chemicals of one pound or greater are shown in this table. & \\
\hline
\end{tabular}


Table C-5. IF-627 maximum chemical inventory, in pounds, for the period of December 1, 2016 through November 30, 2017.

\begin{tabular}{|l|c|c|}
\hline Chemical CAS & Chemical Name & Maximum (lbs) $^{\mathbf{a}}$ \\
\hline $1310-73-2$ & Sodium hydroxide & 2.12415 \\
\hline $110-54-3$ & Hexane & 2.36625 \\
\hline $71-43-2$ & Benzene & 2.640663796 \\
\hline $27323-41-7$ & Triethanolamine dodecylbenzene \\
& sulfonate & 4.2545475 \\
\hline $8042-47-5$ & mineral oil & 4.590784488 \\
\hline $67-64-1$ & Acetone & 10.2 \\
\hline a. Only chemicals of one pound or greater are shown in this table. & \\
\hline
\end{tabular}


Table C-6. IF-638 maximum chemical inventory, in pounds, for the period of December 1, 2016 through November 30, 2017.

\begin{tabular}{|l|c|c|}
\hline Chemical CAS & Chemical Name & Maximum (lbs) $^{\mathbf{a}}$ \\
\hline $7440-36-0$ & Antimony & 1.000077162 \\
\hline $7440-22-4$ & Silver & 1.11 \\
\hline $67-64-1$ & Acetone & 1.352896519 \\
\hline $7439-92-1$ & Lead & 1.408129943 \\
\hline $8042-47-5$ & mineral oil & 2.061675 \\
\hline $1310-73-2$ & Sodium hydroxide & 2.12415 \\
\hline $100-42-5$ & Styrene & 3.432139393 \\
\hline $131-11-3$ & Dimethyl phthalate & 3.644749798 \\
\hline $1338-23-4$ & Methyl ethyl ketone peroxide & 4.049721998 \\
\hline $7440-02-0$ & Nickel & 5 \\
\hline $7440-47-3$ & Chromium & 5.0000005 \\
\hline $7440-50-8$ & Copper & 6.0275 \\
\hline a. Only chemicals of one pound or greater are shown in this table. & \\
\hline
\end{tabular}


Table C-7. IF-655 maximum chemical inventory, in pounds, for the period of December 1, 2016 through November 30, 2017.

\begin{tabular}{|c|c|c|}
\hline Chemical CAS & Chemical Name & Maximum (lbs) $^{\mathrm{a}}$ \\
\hline $75-36-5$ & Acetyl chloride & 1.080265204 \\
\hline 10101-89-0 & Sodium phosphate, tribasic & 1.102311432 \\
\hline $143-33-9$ & Sodium cyanide & 1.102311432 \\
\hline 7758-98-7 & Cupric sulfate & 1.102311432 \\
\hline $79-11-8$ & Chloroacetic acid & 1.102311432 \\
\hline $10043-01-3$ & Aluminum sulfate & 1.102311433 \\
\hline $65-85-0$ & Benzoic acid & 1.102334316 \\
\hline $628-63-7$ & Amyl acetate & 1.120585369 \\
\hline $1185-57-5$ & Ferric ammonium citrate & 1.23826247 \\
\hline $631-61-8$ & Ammonium acetate & 1.271754025 \\
\hline $75-15-0$ & Carbon disulfide & 1.386348493 \\
\hline $107-06-2$ & 1,2-Dichloroethane & 1.522342678 \\
\hline 7789-06-2 & Strontium chromate & 1.763698291 \\
\hline $110-16-7$ & Maleic acid & 2.171553522 \\
\hline $79-00-5$ & 1,1,2-Trichloroethane & 2.200553164 \\
\hline $75-79-6$ & Methyltrichlorosilane & 2.204622864 \\
\hline 7782-86-7 & Mercurous nitrate & 2.204622864 \\
\hline $1327-53-3$ & Arsenic trioxide & 2.204622865 \\
\hline $7778-54-3$ & Calcium hypochlorite & 2.204622865 \\
\hline 78-83-1 & Isobutyl alcohol & 2.204622865 \\
\hline $100-41-4$ & Ethylbenzene & 2.31464504 \\
\hline $1341-49-7$ & Ammonium bifluoride & 2.504502865 \\
\hline $85-68-7$ & Butyl benzyl phthalate & 2.562002493 \\
\hline $12125-02-9$ & Ammonium chloride & 2.564893457 \\
\hline $123-31-9$ & Hydroquinone & 2.854524425 \\
\hline 7681-49-4 & Sodium fluoride & 3.170247671 \\
\hline $74-89-5$ & Methanamine & 3.217867534 \\
\hline $78-93-3$ & Methyl ethyl ketone & 3.24880382 \\
\hline $123-86-4$ & Butyl acetate & 3.861125 \\
\hline $75-36-5$ & Acetyl chloride & 1.080265204 \\
\hline 1314-62-1 & Vanadium pentoxide & 4.102320203 \\
\hline $71-43-2$ & Benzene & 4.310269272 \\
\hline $71-55-6$ & 1,1,1-Trichloroethane & 4.373883579 \\
\hline $75-56-9$ & Oxirane, methyl- & 4.450085277 \\
\hline $109-99-9$ & Furan, tetrahydro- & 4.647671451 \\
\hline $111-42-2$ & Diethanolamine & 4.748144148 \\
\hline $7681-52-9$ & Sodium hypochlorite & 5.148719792 \\
\hline $3012-65-5$ & Ammonium citrate dibasic & 5.511557162 \\
\hline $1330-20-7$ & Xylene (mixed isomers) & 6.061745796 \\
\hline $79-06-1$ & Acrylamide & 6.116137349 \\
\hline $75-25-2$ & Bromoform & 6.359598643 \\
\hline $64-18-6$ & Formic acid & 6.645010619 \\
\hline $10039-32-4$ & Sodium phosphate, dibasic & 6.689681618 \\
\hline $79-34-5$ & 1,1,2,2-Tetrachloroethane & 6.900734121 \\
\hline $127-18-4$ & Perchloroethylene & 7.118242214 \\
\hline $7440-36-0$ & Antimony & 7.155281586 \\
\hline
\end{tabular}




\begin{tabular}{|c|c|c|}
\hline $21908-53-2$ & Mercuric oxide & 7.771856428 \\
\hline 7782-63-0 & Ferrous sulfate & 8.730306546 \\
\hline $56-23-5$ & Carbon tetrachloride & 8.75747323 \\
\hline $60-00-4$ & $\begin{array}{l}\text { Ethylenediamine-tetraacetic acid } \\
\text { (EDTA) }\end{array}$ & 8.818491474 \\
\hline $79-01-6$ & Trichloroethylene & 9.627709306 \\
\hline $7722-84-1$ & $\begin{array}{c}\text { Hydrogen peroxide (Conc.> } \\
52 \%)\end{array}$ & 11.1949515 \\
\hline 7664-41-7 & Ammonia & 11.24721865 \\
\hline $7440-22-4$ & Silver & 11.67094013 \\
\hline 1066-33-7 & Ammonium bicarbonate & 14.33004862 \\
\hline 7720-78-7 & Ferrous sulfate & 14.33004862 \\
\hline 7786-81-4 & Nickel sulfate & 15.06897 \\
\hline 7664-39-3 & Hydrofluoric acid & 16.8847344 \\
\hline $540-84-1$ & 2,2,4-Trimethylpentane & 19.93327072 \\
\hline 7646-85-7 & Zinc chloride & 20.25394079 \\
\hline 1336-21-6 & Ammonium hydroxide & 21.3489202 \\
\hline $64-19-7$ & Acetic acid & 22.95844212 \\
\hline $75-05-8$ & Acetonitrile & 23.88425036 \\
\hline $77-92-9$ & citric acid & 27.40325917 \\
\hline $75-07-0$ & Acetaldehyde & 28.63478374 \\
\hline $110-82-7$ & Cyclohexane & 28.70002147 \\
\hline $123-91-1$ & 1,4-Dioxane & 30.46467806 \\
\hline $75-21-8$ & Ethylene oxide & 30.46470283 \\
\hline 7558-79-4 & Sodium phosphate, dibasic & 30.74919696 \\
\hline $75-09-2$ & Dichloromethane & 41.372742 \\
\hline $107-21-1$ & Ethylene glycol & 45.50756502 \\
\hline $110-54-3$ & Hexane & 45.91181947 \\
\hline $67-66-3$ & Chloroform & 45.98614748 \\
\hline $7632-00-0$ & Sodium nitrite & 50.33883749 \\
\hline $7440-50-8$ & Copper & 64.56656693 \\
\hline $108-88-3$ & Toluene & 65.12091907 \\
\hline 7664-93-9 & Sulfuric acid & 75.40624261 \\
\hline $7440-66-6$ & Zinc & 89.46343819 \\
\hline 7647-01-0 & Hydrochloric acid & 93.29133811 \\
\hline $7440-38-2$ & Arsenic & 93.83473888 \\
\hline $7440-43-9$ & Cadmium & 97.54899102 \\
\hline $67-64-1$ & Acetone & 99.7593414 \\
\hline $1310-58-3$ & Potassium hydroxide & 103.1212531 \\
\hline $8042-47-5$ & mineral oil & 105.10721 \\
\hline 7664-38-2 & Phosphoric acid & 106.4544126 \\
\hline $1310-73-2$ & Sodium hydroxide & 110.8343885 \\
\hline 7439-92-1 & Lead & 115.2127499 \\
\hline $67-56-1$ & Methanol & 148.7886621 \\
\hline $50-00-0$ & Formaldehyde & 172.3534664 \\
\hline $7440-47-3$ & Chromium & 180.7968998 \\
\hline 7440-02-0 & Nickel & 472.8102625 \\
\hline
\end{tabular}


Table C-8. IF-657 maximum chemical inventory, in pounds, for the period of December 1, 2016 through November 30, 2017.

\begin{tabular}{|l|c|c|}
\hline Chemical CAS & Chemical Name & Maximum (lbs) $^{\mathbf{a}}$ \\
\hline $7439-92-1$ & Lead & 1.0000005 \\
\hline $27176-87-0$ & Dodecylbenzenesulfonic acid & 1.04125 \\
\hline $78-93-3$ & Methyl ethyl ketone & 1.598150944 \\
\hline $100-42-5$ & Styrene & 2.16 \\
\hline $8042-47-5$ & mineral oil & 2.633821998 \\
\hline $109-99-9$ & Furan, tetrahydro- & 2.675866725 \\
\hline $85-68-7$ & Butyl benzyl phthalate & 2.84886 \\
\hline $1310-73-2$ & Sodium hydroxide & 3.226461431 \\
\hline $7440-22-4$ & Silver & 6.7 \\
\hline $7440-66-6$ & Zinc & 7.5 \\
\hline $7440-02-0$ & Nickel & 7.902418242 \\
\hline $7664-93-9$ & Sulfuric acid & 9.920093661 \\
\hline $7664-38-2$ & Phosphoric acid & 12.411935 \\
\hline $7440-50-8$ & Copper & 12.57731143 \\
\hline $101-68-8$ & MDI & 15.19392 \\
\hline $7439-97-6$ & Mercury & 18.9924 \\
\hline $1309-64-4$ & Antimony trioxide & 87.12669562 \\
\hline a. Only chemicals of one pound or greater are shown in this table. & \\
\hline
\end{tabular}


Table C-9. IF-732 maximum chemical inventory, in pounds, for the period of December 1, 2016 through November 30, 2017.

\begin{tabular}{|l|c|c|}
\hline Chemical CAS & Chemical Name & Maximum (lbs) $^{\mathbf{a}}$ \\
\hline $92-52-4$ & Biphenyl & 7.860531757 \\
\hline $98-82-8$ & Cumene & 7.862463566 \\
\hline $100-41-4$ & Ethylbenzene & 8.558880794 \\
\hline $91-20-3$ & Naphthalene & 9.550864833 \\
\hline $110-80-5$ & 2 -Ethoxyethanol & 1931.80923 \\
\hline $1330-20-7$ & Xylene (mixed isomers) & 1940.374872 \\
\hline $106-44-5$ & p-Cresol & 1961.58888 \\
\hline $108-39-4$ & m-Cresol & 1961.58888 \\
\hline $108-88-3$ & Toluene & 1961.58888 \\
\hline $108-95-2$ & Phenol & 1961.58888 \\
\hline $71-43-2$ & Benzene & 1961.58888 \\
\hline $95-48-7$ & o-Cresol & 1961.58888 \\
\hline $108-05-4$ & Acetic acid ethenyl ester & 1961.594765 \\
\hline a. Only chemicals of one pound or greater are shown in this table. & \\
\hline
\end{tabular}




\section{Exhibit D}

\section{INL Research Complex (IRC) Accidental Spill Prevention Plan, PLN-3530}


Idaho National Laboratory

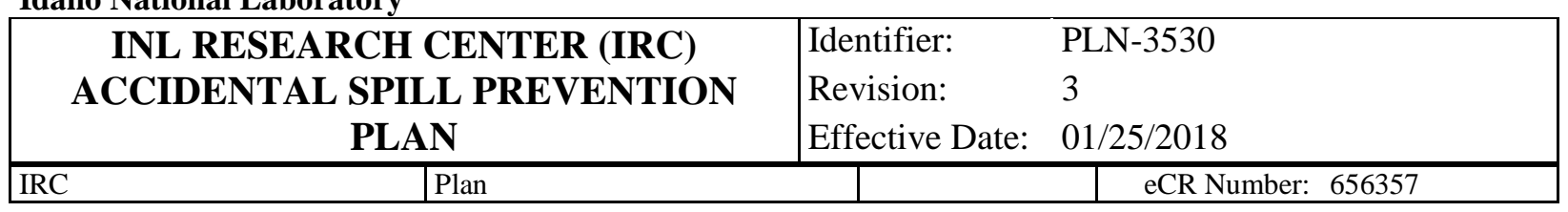

\section{REVISION LOG}

\begin{tabular}{|c|c|c|c|}
\hline Rev. & Date & Affected Pages & Revision Description \\
\hline 0 & $08 / 12 / 10$ & All & New document. \\
\hline 1 & $11 / 28 / 12$ & All & See eCR 609456. \\
\hline 2 & $01 / 03 / 18$ & All & See eCR 655181 \\
\hline$\underline{3}$ & $01 / 25 / 18$ & 1,2 & $\begin{array}{l}\text { Table 1. IRC buildings regulated under PER-33. } \\
\text { Deleted IF-605, IF-663, IF-683, IF-731, and IF-689. } \\
\text { These building are NOT regulated under PER-33. }\end{array}$ \\
\hline & & & \\
\hline & & & \\
\hline & & & \\
\hline & & & \\
\hline & & & \\
\hline & & & \\
\hline & & & \\
\hline & & & \\
\hline & & & \\
\hline
\end{tabular}


Idaho National Laboratory

\begin{tabular}{|c|ll|}
\hline INL RESEARCH CENTER (IRC) & Identifier: & PLN-3530 \\
ACCIDENTAL SPILL PREVENTION & Revision: & 3 \\
PLAN & Effective Date: & $01 / 25 / 2018$ \\
\hline
\end{tabular}

CONTENTS

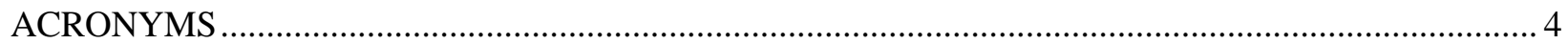

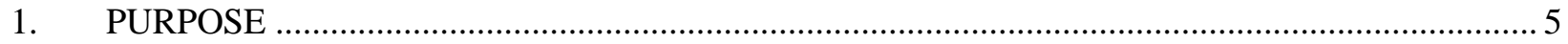

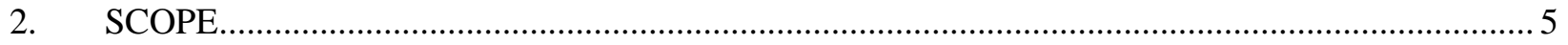

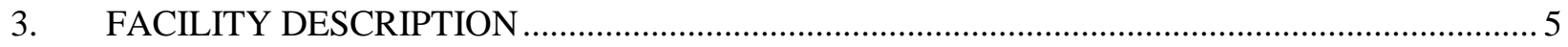

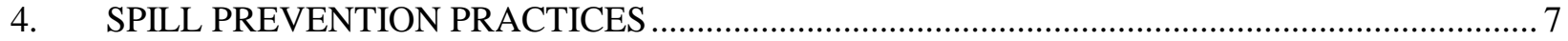

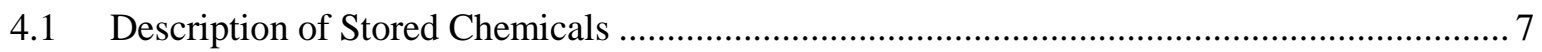

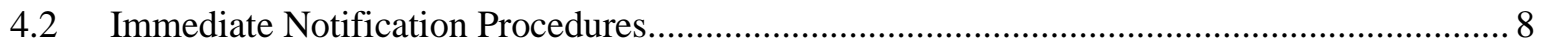

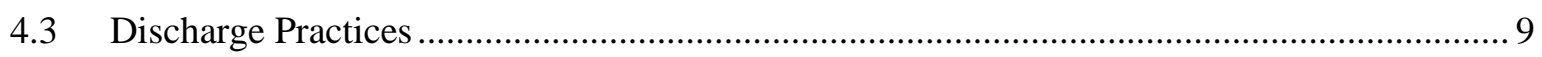

4.4 Procedures to Prevent Adverse Impact from Accidental or Slug Discharge ......................... 9

4.4.1 Storage Area Inspection and Maintenance.................................................................. 9

4.4.2 Material Handling and Transfer (including Loading/Unloading) .............................. 9

4.4.3 Containment Measures, Structures, and Equipment .................................................. 10

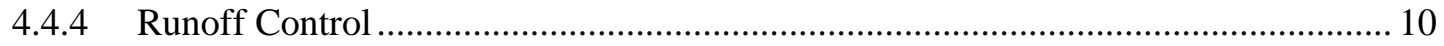

4.4.5 Emergency Response Measures and Equipment.................................................. 10

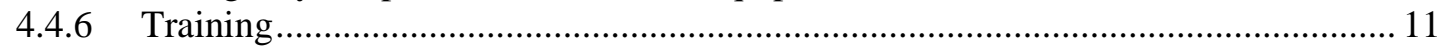

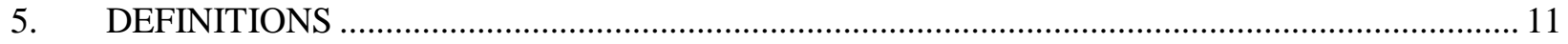

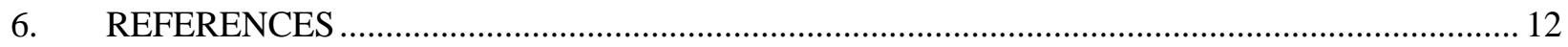

\section{TABLES}

Table 1. IRC buildings regulated under PER-33. ............................................................................. 5

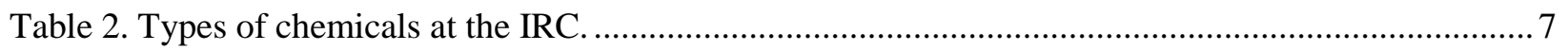


Idaho National Laboratory

\begin{tabular}{|c|ll|}
\hline INL RESEARCH CENTER (IRC) & Identifier: & PLN-3530 \\
ACCIDENTAL SPILL PREVENTION & Revision: & 3 \\
PLAN & Effective Date: & $01 / 25 / 2018$ \\
\hline
\end{tabular}

\section{ACRONYMS}

ASPP Accidental Spill Prevention Plan

AST Aboveground Storage Tank

BS Building Specialist

CFR Code of Federal Regulations

DBM Duty Building Manager

DOE Department of Energy

ES\&H Environmental, Safety, and Health

FCM Facility Complex Manager

HVAC Heating, Ventilation, and Air Conditioning

INL Idaho National Laboratory

IRC INL Research Center

POTW Publicly Owned Treatment Works

RCRA Resource Conservation and Recovery Act

REC Research and Education Campus

SAA Satellite Accumulation Area

SNT Spill Notification Team

TAA Temporary Accumulation Area

UST Underground Storage Tank 


\begin{tabular}{|c|ll|}
\hline INL RESEARCH CENTER (IRC) & Identifier: & PLN-3530 \\
ACCIDENTAL SPILL PREVENTION & Revision: & 3 \\
PLAN & Effective Date: & $01 / 25 / 2018$ \\
\hline
\end{tabular}

\section{PURPOSE}

The purpose of the INL Research Center (IRC) accidental spill prevention plan (ASPP) is to describe discharge practices, chemical storage, notification procedures, and procedures to prevent adverse impact from accidental or slug discharges of pollutants into the Idaho Falls wastewater collection system.

\section{SCOPE}

The IRC ASPP establishes practices for preventing accidental discharge (i.e., spills) of pollutants or slug discharges into the Idaho Falls wastewater collection system, as required by the IRC "Industrial Wastewater Acceptance Permit,” INL document PER-33. This ASPP applies to pollutants used on properties identified in PER-33. All INL programs or projects using pollutants on these properties that are at risk of being spilled (or released) to the Idaho Falls wastewater collection system are responsible for meeting the intent and requirements of this IRC ASPP. This ASPP addresses the discharge of pollutants, as defined by Title 8 of the Idaho Falls Code of Ordinances, "Public Utilities and Property," Chapter 1, "Sewers."

\section{FACILITY DESCRIPTION}

The IRC is a group of buildings, located on United States Department of Energy (DOE) property and part of the INL's Research and Education Campus (REC). The IRC buildings that are subject to PER-33 are listed in Table 2 below, along with a brief description of the materials that are potential pollutants if discharged to the Idaho Falls wastewater collection system. All IRC building sinks and floor drains ultimately discharge (along with hand soap and janitorial products) to the city's system. INL drawing 180052 shows the IRC sewer piping system and its tie-in to the city's main. Access to IRC buildings is controlled, with security personnel readily available.

Table 2. IRC buildings regulated under PER-33.

\begin{tabular}{|c|l|l|}
\hline $\begin{array}{c}\text { Building } \\
\text { No. }\end{array}$ & \multicolumn{1}{|c|}{ Building Name/Description } & \multicolumn{1}{|c|}{$\begin{array}{c}\text { Potential Wastewater } \\
\text { Pollutants }\end{array}$} \\
\hline IF-601 & $\begin{array}{l}\text { Research Office Building No. 1 } \\
\text { IF-601 is a single-story office complex. This building } \\
\text { provides office space for engineers, scientists, and } \\
\text { technicians. }\end{array}$ & Janitorial products \\
\hline IF-602 & $\begin{array}{l}\text { IRC Office Building } \\
\text { The IRC Office Building provides office space for } \\
\text { engineer, scientist, and technician, as well as seismic and } \\
\text { scanning transmission electronic microscope activities. }\end{array}$ & $\begin{array}{l}\text { Heating, ventilation, and air } \\
\text { conditioning (HVAC) water } \\
\text { treatment chemicals } \\
\text { Janitorial products }\end{array}$ \\
& $\begin{array}{l}\text { Facility maintenance products } \\
\text { Diesel fuel } \\
\text { 27-gal aboveground } \\
\text { 2torage tank (AST) day } \\
\text { tank for emergency } \\
\text { generator, NW of building } \\
\text { 600-gal Underground } \\
\text { Storage Tank (UST) for } \\
\text { emergency generator, NW } \\
\text { of building }\end{array}$ \\
\hline
\end{tabular}


Idaho National Laboratory

\begin{tabular}{|c|c|c|c|}
\hline \multicolumn{2}{|c|}{$\begin{array}{c}\text { INL RESEARCH CENTER (IRC) } \\
\text { ACCIDENTAL SPILL PREVENTION } \\
\text { PLAN }\end{array}$} & $\begin{array}{l}\text { Identifier: } \\
\text { Revision: } \\
\text { Effective Date: }\end{array}$ & \\
\hline $\begin{array}{l}\text { Building } \\
\text { No. }\end{array}$ & \multicolumn{2}{|c|}{ Building Name/Description } & $\begin{array}{c}\text { Potential Wastewater } \\
\text { Pollutants }\end{array}$ \\
\hline IF-603 & \multicolumn{2}{|c|}{$\begin{array}{l}\text { IRC Laboratory Building } \\
\text { This building is the primary science and engineering } \\
\text { laboratory at the REC. There are about } 45 \text { analytical } \\
\text { research labs located in the A and B wings, including } \\
\text { biology, chemistry, physics, ceramics, laser, hydrology, } \\
\text { and subsurface sciences disciplines. There are also } \\
\text { several spectrometry labs. There is a bio-wing high bay } \\
\text { on the east side of building. Stored energy, } \\
\text { welding/joining/spray, materials testing, metallography, } \\
\text { and measurement and operability labs are located in the } \\
\text { C wing. A craft area includes general carpenter, } \\
\text { mechanic, pipefitter, electrician and electronics shops } \\
\text { that support facility maintenance, as well as the } \\
\text { staging/mockup area. Machine and weld shops support } \\
\text { experiment fabrication and assembly. IF-603 has } \\
\text { numerous small storage areas (including a temporary } \\
\text { accumulation area [TAA] in room A6 and satellite } \\
\text { accumulation areas [SAAs] in several labs), two outside } \\
\text { cylinder staging areas along the west end of the north } \\
\text { side, and an effluent monitoring station located on the } \\
\text { west side of the building. }\end{array}$} & $\begin{array}{l}\text { Janitorial products } \\
\text { Extensive laboratory } \\
\text { chemicals } \\
\text { HVAC water treatment } \\
\text { chemicals } \\
\text { Facility maintenance products } \\
\text { Hazardous waste } \\
\text { Radionuclides } \\
\text { Compressor blowdown } \\
\text { Water softener discharge } \\
\text { Biological agents } \\
\text { Diesel fuel } \\
\text { - } 56 \text {-gal AST day tank for } \\
\quad \text { emergency generator, } \mathrm{N} \text { of } \\
\text { building } \\
\text { - 2,500-gal UST for } \\
\text { emergency generator, } \mathrm{N} \text { of } \\
\text { building }\end{array}$ \\
\hline IF-611 & \multicolumn{2}{|c|}{$\begin{array}{l}\text { National Security Laboratory } \\
\text { IF-611 is a national security laboratory that supports } \\
\text { classified research and development. The building houses } \\
\text { four classified laboratory bays. }\end{array}$} & $\begin{array}{l}\text { Minimal laboratory chemicals } \\
\text { Janitorial products } \\
\text { Compressor blowdown } \\
\text { Water softener discharge }\end{array}$ \\
\hline IF-627 & \multicolumn{2}{|c|}{$\begin{array}{l}\text { Systems Analysis Facility } \\
\text { This building is currently used as an office area with two } \\
\text { lab areas currently used for electronic and material stress } \\
\text { research.. }\end{array}$} & $\begin{array}{l}\text { Janitorial products } \\
\text { Compressor blowdown }\end{array}$ \\
\hline IF-638 & \multicolumn{2}{|c|}{$\begin{array}{l}\text { IRC Physics Laboratory } \\
\text { The Applied Physics Laboratory includes a physics } \\
\text { laboratory and test equipment; work is conducted } \\
\text { utilizing sealed radiological sources. }\end{array}$} & $\begin{array}{l}\text { Minimal laboratory chemicals } \\
\text { Janitorial products }\end{array}$ \\
\hline IF-655 & \multicolumn{2}{|c|}{$\begin{array}{l}\text { IRC Chemical Storage Facility } \\
\text { This building is used to store bulk chemicals and prepare } \\
\text { them for lab use. The chemical storage space consists of } \\
\text { a general chemical room, acid storage room, caustic } \\
\text { storage room, flammable liquids storage room, } \\
\text { flammable solids storage room, and an oxidizer storage } \\
\text { room. The flammable liquids, flammable solids, and } \\
\text { oxidizer storage rooms are separated from the remainder } \\
\text { of the building by rated firewalls. There are no } \\
\text { wastewater drains in this building. Unheated cylinder } \\
\text { storage is provided on the east side of the building. }\end{array}$} & $\begin{array}{l}\text { Extensive laboratory } \\
\text { chemicals } \\
\text { Janitorial products }\end{array}$ \\
\hline
\end{tabular}


Idaho National Laboratory

\begin{tabular}{|c|c|c|c|}
\hline \multicolumn{2}{|c|}{$\begin{array}{c}\text { INL RESEARCH CENTER (IRC) } \\
\text { ACCIDENTAL SPILL PREVENTION } \\
\text { PLAN }\end{array}$} & $\begin{array}{l}\text { Identifier: } \\
\text { Revision: } \\
\text { Effective Date: }\end{array}$ & $\begin{array}{l}\text { PLN-3530 } \\
3 \\
01 / 25 / 2018\end{array}$ \\
\hline $\begin{array}{l}\text { Building } \\
\text { No. }\end{array}$ & \multicolumn{2}{|c|}{ Building Name/Description } & $\begin{array}{c}\text { Potential Wastewater } \\
\text { Pollutants }\end{array}$ \\
\hline IF-657 & \multicolumn{2}{|c|}{$\begin{array}{l}\text { INL Engineering Demonstration Facility } \\
\text { This large-scale demonstration/research building } \\
\text { supports multiple, varying research projects in eight high } \\
\text { bays and one prep lab, and includes a mezzanine control } \\
\text { room and equipment lab. }\end{array}$} & $\begin{array}{l}\text { Janitorial products } \\
\text { Laboratory chemicals } \\
\text { Mineral oil (10 350-gal ASTs } \\
\text { in E-I Bay mezzanine) } \\
\text { Compressor blowdown } \\
\text { Water softener discharge }\end{array}$ \\
\hline IF-732 & \multicolumn{2}{|c|}{$\begin{array}{l}\text { North Fire Pump House - This building houses } \\
\text { equipment that provides backup fire protection in the } \\
\text { event that city water supply is interrupted. }\end{array}$} & $\begin{array}{l}\text { Diesel fuel (300-gal AST) } \\
\text { Motor oil }\end{array}$ \\
\hline
\end{tabular}

\section{SPILL PREVENTION PRACTICES}

\subsection{Description of Stored Chemicals}

A wide variety of products and chemicals are stored and used at IRC buildings; typical categories and types are listed in Table 2.

Table 2. Types of chemicals at the IRC.

\begin{tabular}{|c|c|}
\hline Category & Type \\
\hline Fuels, coolants, and lubricants & $\begin{array}{ll}\text { - } & \text { Diesel fuel } \\
\text { - } & \text { Motor oil } \\
\text { - } & \text { Antifreeze } \\
\text { - } & \text { Mineral oil } \\
\end{array}$ \\
\hline Laboratory chemicals & $\begin{array}{ll}\text { - } & \text { Standards } \\
\text { - } & \text { Reagents } \\
\text { - } & \text { Flammable and bases } \\
\text { - } & \text { Organics } \\
\text { - } & \text { Alcohols } \\
\text { - } & \text { Metals } \\
\text { - } & \text { Biological agents } \\
\text { - } & \text { Radionuclides }\end{array}$ \\
\hline Maintenance products & $\begin{array}{l}\text { - } \text { Janitorial cleaners } \\
\text { - } \text { Paints and stains } \\
\text { - } \text { Epoxies } \\
\text { - Solvents } \\
\text { - Wood finishing products } \\
\text { - } \text { Metal-working chemicals } \\
\text { - } \text { Refrigerants } \\
\text { HVAC water treatment chemicals (corrosives, inhibitors, and }\end{array}$ \\
\hline
\end{tabular}


Idaho National Laboratory

\begin{tabular}{|c|c|}
\hline $\begin{array}{c}\text { INL RESEARCH CENTER (IRC) } \\
\text { ACCIDENTAL SPILL PREVENTION } \\
\text { PLAN }\end{array}$ & \begin{tabular}{|ll} 
Identifier: & PLN-3530 \\
Revision: & 3 \\
Effective Date: & $01 / 25 / 2018$
\end{tabular} \\
\hline \multirow{2}{*}{ Category } & Type \\
\hline & \\
\hline
\end{tabular}

Large chemical inventories are stored at the IRC Chemical Storage Facility, IF-655, in controlled areas with appropriate secondary containment. There are no drains in IF-655. Chemicals are checked out/in to/from the research areas, as applicable. Chemical containers are not generally opened in IF-655; the desired quantities are removed in the labs using appropriate chemical handling protocol. The checkedout container may then be returned to IF-655.

Smaller quantities of laboratory type chemicals are stored in the laboratories in cabinets appropriate for the hazards (e.g., separate corrosives, reactives, and flammables cabinets).

Fuels, coolants, lubricants and facility maintenance products are generally stored near their place of use. HVAC water treatment chemicals for IF-603 are stored in a locked storage room with secondary containment or at IF-655.

\subsection{Immediate Notification Procedures}

PER-33 requires that the INL immediately notify the City of Idaho Falls in the event of an accidental or slug discharge (see definition in Section 5). Such notification must also be given for discharges that violate the prohibited discharge standards and the local pollutant limits.

The INL implements this requirement by directing its employees to promptly notify their manager/supervisor after becoming aware of a discharge violation. The manager/supervisor/employee must immediately notify the Program Environmental Lead (PEL), or the Spill Notification Team (208 241-6400) if the PEL is not available. If the SNT cannot be reached, contact the Warning Communication Center (WCC) at 208 526-1515, and request the WCC notify the SNT.

REC facility management works with the reporting manager/supervisor/employee to determine if the spill is reportable and notifies the City of Idaho Falls and Publicly Owned Treatment Works (POTW) operator at $612-8108$ or $612-8476$, as required. The notification is to include the concentration and volume of the discharge and the corrective actions proposed or taken to reduce adverse impact to the POTW.

Typically, the following information is established and provided to the SNT:

- Date and time of spill or discovery of spill

- Identity of substance spilled (using observer's best technical judgment)

- Quantity spilled (best estimate)

- Clear description of spill location

- Source of spill (or probable source if unsure)

- Existing or potential hazards

- Injuries or casualties involved

- $\quad$ Name and phone number of person making verbal report

- Any other relevant circumstances.

Managers/supervisors must perform follow-up reporting for a spill in compliance with all applicable PER-33 requirements, PLN-3574, "IRC Support Activities Spill Prevention, Control, and Countermeasure (SPCC) Plan,”, PLN-3969 “IRC Research Activities Spill Prevention, Control, and Countermeasure (SPCC) Plan,” and INL procedures. 


\begin{tabular}{|c|ll|}
\hline INL RESEARCH CENTER (IRC) & Identifier: & PLN-3530 \\
ACCIDENTAL SPILL PREVENTION & Revision: & 3 \\
PLAN & Effective Date: & $01 / 25 / 2018$ \\
\hline
\end{tabular}

\subsection{Discharge Practices}

The handling of chemicals and related waste in IRC buildings is controlled using procedures and training programs designed to minimize/eliminate the potential for spills.

Procedure development requires an evaluation of the proposed scope of work and the hazards created by the work, followed by the mitigations to those hazards, the controls needed to operate successfully and safely, the training required to perform the work, and how to provide feedback on the work control process itself. As part of the work control process, subject matter experts may be consulted to provide guidance and input to activity managers in the areas of safety, health, environmental compliance, and quality.

Routine discharges to IRC building sinks and drains are limited to unregulated and nonhazardous material. Signs are conspicuously posted at or near sinks and drains in laboratories and research areas advising personnel of prohibited discharges and whom to call if a spill, slug, or accidental discharge to the environment occurs. Areas excluded from these postings are restrooms, coffee alcoves, janitor closets, and similar locations where normal office discharges (sanitary, potable water, condensate, etc.) occur.

Training programs are in place (see Section 4.4.6) for proper hazardous material handling, disposal practices, and spill/release prevention, including accidental discharge/slug control to the sewer system. This includes containing spilled material to avoid discharge into a sanitary sewer through floor drains, into a storm water drain, or off property under the jurisdiction of the INL. Required INL emergency preparedness training and chemical hygiene training must be completed.

\subsection{Procedures to Prevent Adverse Impact from Accidental or Slug Discharge}

\subsubsection{Storage Area Inspection and Maintenance}

IRC chemical, radioactive material, and hazardous waste storage areas are inspected routinely for evidence of leaks, container deterioration, and secondary containment integrity. The inspection program helps ensure the early detection of problems and that corrective maintenance is initiated in a timely manner.

Chemical storage is managed per Chemical Services procedures. Inspection of the SAAs and TAA is performed per Resource Conservation and Recovery Act (RCRA) requirements for Small Quantity Generators. Radioactive Materials Areas are managed per the INL Radiation Control Manual.

\subsubsection{Material Handling and Transfer (including Loading/Unloading)}

Containers are transferred and handled in a manner that reduces the likelihood of a spill. Containers are checked for damage, leaks, labels, and general integrity prior to transfer or acceptance. Inventories of chemicals and wastes are kept for accountability.

Chemicals are dispensed to research areas in small quantities, as applicable, from the IRC Chemical Storage Facility, IF-655.

Waste, including expended chemicals, is collected in hazardous waste SAAs within the laboratories. The waste is removed from the laboratories on a routine schedule and placed in a TAA that has secondary containment and monitoring.

Container loading and unloading operations include unloading containers from trucks and trailers using forklifts or cranes and moving containers between storage areas and laboratories or other 
Idaho National Laboratory

\begin{tabular}{|c|ll|}
\hline INL RESEARCH CENTER (IRC) & Identifier: & PLN-3530 \\
ACCIDENTAL SPILL PREVENTION & Revision: & 3 \\
PLAN & Effective Date: & $01 / 25 / 2018$ \\
\hline
\end{tabular}

chemical-use areas. Loading/unloading operations are performed by trained and qualified personnel. Training may include hoisting and rigging and/or heavy equipment certifications.

\subsubsection{Containment Measures, Structures, and Equipment}

Floor drains. IRC laboratories listed in PER-33 in which research activities have large volumes of pollutants typically have the floor drains plugged to prevent discharge to the wastewater system in the event pollutants are spilled onto the floor.

Secondary containment. Waste containers in SAAs are normally stored on portable secondary containment structures that have the capacity to contain liquid waste spills. The floor of the TAA in room A6 is equipped for secondary containment, and the floor drain is plugged. The IRC Chemical Storage Facility, IF-655 also includes secondary containment provisions.

The two diesel fuel USTs are doubly contained tanks equipped with interstitial leak monitoring.

IF-603 pH effluent monitoring system. The $\mathrm{pH}$ of lab effluent from the IRC lab building (IF-603) is continuously monitored. (Note that effluent from the mechanical rooms, restrooms, and janitorial closets bypasses the $\mathrm{pH}$ monitoring system.) The $\mathrm{pH}$ effluent monitoring building is a metal shed located near the west side of IF-603. All actions required to mitigate a pH event are performed in this building. INL drawings 176607 through 176610, 176612 through 176614, and 513838 detail the IRC effluent monitoring system.

The $\mathrm{pH}$ monitor alarms for low $\mathrm{pH}$ (acidic) and for high $\mathrm{pH}$ (caustic). During a $\mathrm{pH}$ event where the effluent nears PER-33 discharge limits, the building effluent is automatically rerouted and recirculated into a 2,000-gallon holding tank for automatic neutralization. The alarm notifies the off-shift duty building manager (DBM) or building specialist (BS) (day shift) by cell phone text message via the building Carrier i-Vu digital control system. The DBM/BS responds to $\mathrm{pH}$ alarms.

City of Idaho Falls effluent monitoring program. Sampling for self and unscheduled monitoring is performed at a monitoring station on the east side of North Boulevard, at the entrance to the IRC. The regulated IRC buildings are also subject to a scheduled effluent monitoring program.

\subsubsection{Runoff Control}

Contamination of the City of Idaho Falls sewer system due to runoff from IRC activities is highly unlikely because chemicals and waste are stored indoors in sealed containers. The IRC buildings are greater than $150 \mathrm{ft}$ from the sewer system tie-in to the City's pipeline. In addition, several shallow injection wells are installed on the IRC campus to redirect irrigation and storm water from building foundations and help mitigate runoff. Building additions and modifications go through a thorough design change process during which runoff considerations are addressed.

\subsubsection{Emergency Response Measures and Equipment}

Emergency spill response and management consist of, but are not limited to, maintaining relevant emergency response spill management supplies and having them readily available, maintaining written procedures defining responsibilities during an emergency, and training personnel.

Management and work procedures include instructions for employees and the facility supervisor to respond to and mitigate abnormal or potentially unsafe conditions at IRC facilities. Procedures also provide instructions for emergencies in the hazardous waste SAAs and TAA, and accidental discharges to the City of Idaho Falls sewer system. MCP-3522, "Research \& Education Campus Duty Building Manager,” defines work processes for responding to abnormal situations and alarm responses during offshift and weekend hours. 


\begin{tabular}{|c|ll|}
\hline INL RESEARCH CENTER (IRC) & Identifier: & PLN-3530 \\
ACCIDENTAL SPILL PREVENTION & Revision: & 3 \\
PLAN & Effective Date: & $01 / 25 / 2018$ \\
\hline
\end{tabular}

In IRC buildings listed in PER-33, for chemical use and chemical and waste storage facilities that have potential for accidental discharges to the Idaho Falls sewer system, information regarding what may not be disposed of down the drains and telephone numbers of whom to contact if a spill occurs are conspicuously posted.

The REC maintenance organization responds to hazardous-substance spills in building areas that house non-programmatic organizational processes. They also assume responsibility for responding to spills on or in the properties under the purview of Research and Development Laboratory properties for which no organization or program can be identified, such as parking lots, hallways, foyers, and loading docks.

pH effluent monitoring system. LI-332 includes instructions for responding to a high or low $\mathrm{pH}$ alarm from the IF-603 effluent monitoring station.

Spill control equipment. At potential spill areas, spill control equipment and supplies are available, and employees who work in those areas are adequately trained to use such equipment and supplies. Items commonly used for spill control are as follows:

- Neutralizing agents

- Absorbents

- Commercial solvent and corrosive spill kits

- Personal protective clothing and equipment (e.g., goggles, rubber gloves, rubber boots, aprons, full-face shields, and appropriate respirator)

- Spill control pillows (universal)

- Containers for the management and disposal of spilled and cleanup material

- Secondary containment systems

- $\quad$ Labels and markers

- $\quad$ Fire extinguisher (as appropriate).

\subsubsection{Training}

All INL and subcontract employees receive environmental, safety, and health (ES\&H) awareness training that includes instructions for spill reporting. Laboratory workers also receive chemical hygiene and laboratory awareness training, specifying responsibilities with regard to discharging chemicals to sinks/drains and spill response.

\section{DEFINITIONS}

Discharge. The introduction of pollutants into the POTW from any regulated non-domestic source, by means of pipes, conduits, pumping stations, force mains, constructed drainage ditches, surface water intercepting ditches, and all constructed devices and appliances appurtenant thereto.

Hazardous waste. A solid waste that exhibits the characteristics of hazardous waste (ignitable, reactive, corrosive, or toxic) under Subpart C of 40 Code of Federal Regulations (CFR) 261.20 or is a listed waste under Subpart D of 40 CFR 261.20.

Slug discharge (or slug load). Any discharge at a flow rate or concentration which could cause a violation of the discharge standards or any discharge of a non-routine, episodic nature including, but not limited to, an accidental spill or a non-customary batch discharge. 


\begin{tabular}{|c|ll|}
\hline INL RESEARCH CENTER (IRC) & Identifier: & PLN-3530 \\
ACCIDENTAL SPILL PREVENTION & Revision: & 3 \\
PLAN & Effective Date: & $01 / 25 / 2018$ \\
\hline
\end{tabular}

\section{REFERENCES}

LI-332, “IRC pH Alarms and Associated Responses”

LRD-8000, “Environmental Requirements for Facilities, Processes, Materials and Equipment,” current revision.

MCP-3522, “Research \& Education Campus Duty Building Manager”

PER-33, IRC Industrial Wastewater Acceptance Permit

PLN-3574, “IRC Support Activities Spill Prevention, Control, and Countermeasure (SPCC) Plan”

PLN-3969, “IRC Research Activities Spill Prevention, Control, and Countermeasure (SPCC) Plan” 